\title{
The hemicellulose-degrading enzyme system of the thermophilic bacterium Clostridium stercorarium: comparative characterisation and addition of new hemicellulolytic glycoside hydrolases
}

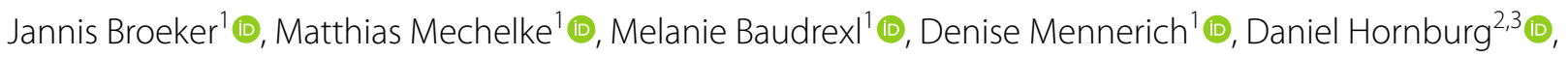

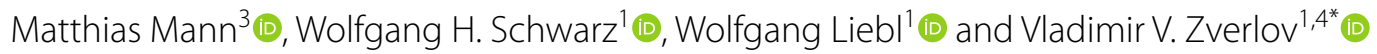

\begin{abstract}
Background: The bioconversion of lignocellulosic biomass in various industrial processes, such as the production of biofuels, requires the degradation of hemicellulose. Clostridium stercorarium is a thermophilic bacterium, well known for its outstanding hemicellulose-degrading capability. Its genome comprises about 50 genes for partially still uncharacterised thermostable hemicellulolytic enzymes. These are promising candidates for industrial applications.

Results: To reveal the hemicellulose-degrading potential of 50 glycoside hydrolases, they were recombinantly produced and characterised. 46 of them were identified in the secretome of $C$. stercorarium cultivated on cellobiose. Xylanases Xyn11A, Xyn10B, Xyn10C, and cellulase Cel9Z were among the most abundant proteins. The secretome of C. stercorarium was active on xylan, $\beta$-glucan, xyloglucan, galactan, and glucomannan. In addition, the recombinant enzymes hydrolysed arabinan, mannan, and galactomannan. 20 enzymes are newly described, degrading xylan, galactan, arabinan, mannan, and aryl-glycosides of $\beta$-D-xylose, $\beta$-D-glucose, $\beta$-D-galactose, $\alpha$-L-arabinofuranose, $\alpha-L-$ rhamnose, $\beta$-D-glucuronic acid, and N-acetyl- $\beta$-D-glucosamine. The activities of three enzymes with non-classified glycoside hydrolase (GH) family modules were determined. Xylanase Xyn105F and $\beta$-D-xylosidase BxI31D showed activities not described so far for their $\mathrm{GH}$ families. 11 of the 13 polysaccharide-degrading enzymes were most active at pH 5.0 to $\mathrm{pH} 6.5$ and at temperatures of $57-76^{\circ} \mathrm{C}$. Investigation of the substrate and product specificity of arabinoxylan-degrading enzymes revealed that only the $\mathrm{GH} 10$ xylanases were able to degrade arabinoxylooligosaccharides. While Xyn10C was inhibited by a-(1,2)-arabinosylations, Xyn10D showed a degradation pattern different to Xyn10B and Xyn10C. Xyn11A released longer degradation products than Xyn10B. Both tested arabinose-releasing enzymes, Arf51B and Axh43A, were able to hydrolyse single- as well as double-arabinosylated xylooligosaccharides.

Conclusions: The obtained results lead to a better understanding of the hemicellulose-degrading capacity of $C$. stercorarium and its involved enzyme systems. Despite similar average activities measured by depolymerisation tests, a closer look revealed distinctive differences in the activities and specificities within an enzyme class. This may lead to synergistic effects and influence the enzyme choice for biotechnological applications. The newly characterised glycoside hydrolases can now serve as components of an enzyme platform for industrial applications in order to
\end{abstract}

\footnotetext{
*Correspondence: vladimir.zverlov@tum.de

1 Department of Microbiology, TUM School of Life Sciences

Weihenstephan, Technical University of Munich, Emil-Ramann-Str. 4,

85354 Freising, Germany

Full list of author information is available at the end of the article
} 
reconstitute synthetic enzyme systems for complete and optimised degradation of defined polysaccharides and hemicellulose.

Keywords: Biomass degradation, Enzyme characterisation, Proteome analysis, Arabinoxylan, Xylanase, Substrate specificity, Product specificity

\section{Background}

Hemicelluloses are heterogeneous polysaccharides in plant cell walls that are characterised by $\beta$-(1,4)-linked backbones with an equatorial configuration [1]. After cellulose, they are the second most common polysaccharides representing about $20-35 \%$ of lignocellulosic biomass [2, 3]. Hemicelluloses have a high structural and chemical diversity. Their backbones are usually branched or substituted with short oligosaccharides, monosaccharides, and organic acids. The major building blocks are pentoses (xylose, arabinose), hexoses (glucose, galactose, mannose), sugar acids (glucuronic acid), acetic acid, and phenolic acids (ferulic acid, $p$-coumaric acid) $[2,4]$. According to the predominant monosaccharide in the main polymeric chain, hemicelluloses are classified into four types of polysaccharides: xylans, mannans, $\beta$-(1,3;1,4)-glucans, and xyloglucans. Further polysaccharides, such as galactans, arabinans, and arabinogalactans, are rather parts of pectin substances and do not share the equatorial $\beta$-(1,4)-linked backbone structure $[1,5]$. Because they are often isolated with the hemicelluloses, they are included in this study. Among hemicelluloses, xylans are the most abundant polysaccharides and the major hemicelluloses in hardwood and grasses $[3,6]$.

Effective enzymatic degradation of hemicelluloses is of great interest for various applications in industrial processes, such as efficient conversion of lignocellulosic biomass to fuels and chemicals, bleaching of paper pulp, and improvement of food properties [2]. The majority of hemicellulolytic enzymes belong to the glycoside hydrolases $(\mathrm{GH})$, which hydrolyse the glycosidic bond between two carbohydrates or a carbohydrate and a non-carbohydrate moiety. Based on amino acid sequence and concomitant structural similarities, the Carbohydrate-Active Enzymes database (CAZy) classifies glycoside hydrolases and further carbohydrate-active enzymes, such as polysaccharide lyases (PL) and carbohydrate esterases (CE), into functional families $[7,8]$.

Saprophytic bacteria degrade lignocellulosic biomass by secreting glycoside hydrolases active on cellulose and hemicellulose [9]. One of the first identified and best characterised cellulolytic bacteria is Clostridium stercorarium $[10,11]$. The Gram-positive, strictly anaerobic and thermophilic bacterium is well known for being a specialist in the hydrolysis of hemicellulose. C. stercorarium degrades polysaccharides with a variety of hemicellulolytic enzymes, ferments a wide range of sugars, hexoses as well as pentoses, and produces acetate, ethanol, $\mathrm{CO}_{2}$, and $\mathrm{H}_{2}$ [10-14]. Recently it was suggested to assign $C$. stercorarium to the new genus Ruminiclostridium and to rename it Ruminiclostridium stercorarium [15].

A number of C. stercorarium enzymes involved in the degradation of polysaccharides have already been characterised $[12,16,17]$. C. stercorarium produces two cellulases that form a two-component cellulase system: Cel9Z (avicelase I, GH9) and Cel48Y (avicelase II, GH48). Cel9Z, which combines endoglucanase and exoglucanase activities, and the exoglucanase Cel48Y act synergistically to degrade crystalline cellulose [18-22]. Three endo-xylanases of C. stercorarium have been described: Xyn11A, Xyn10B, and Xyn10C (sometimes referred to as Xyn10B) [23-25]. The screening of a genomic library revealed seven genes related to arabinoxylan hydrolysis, encoding the three xylanases, two $\alpha-\mathrm{L}$-arabinofuranosidases (Arf43A, Arf51B), and two $\beta$-D-xylosidases (Bxl39A, Bxl3B) [26]. All seven enzymes and the $\beta$-glucosidase Bgl3Z hydrolyse arabinoxylan or degradation products thereof. Four glycoside hydrolases without established involvement in cellulose or xylan degradation have been described: two $\beta$-xylosidases (Xyl43A and Xyl43B), an $\alpha$-galactosidase (Aga36A), and an $\alpha$-glucuronidase (Agu67A) [27-30]. The $\alpha$-L-rhamnosidase Ram78A hydrolyses naringin to prunin and rhamnose and was applied for the production of rhamnose from citrus peel naringin [16, 31]. In addition, an extracellular feruloyl esterase, a pectate lyase (Pel9A), a cellobiose phosphorylase (CepA), and a cellodextrin phosphorylase (CepB) have been characterised [32-34].

Although C. stercorarium is one of the model organisms for carbohydrate-degrading bacteria, only a few individual enzymes and the enzyme systems for hydrolysis of cellulose and xylan have so far been described in detail. In addition, the bacterium produces a number of putative hemicellulolytic enzymes with still unidentified activity awaiting further characterisation for potential applications [35].

In this study, we investigated the majority of glycoside hydrolases from the genome of C. stercorarium DSM 8532 to reach a deeper insight into the polysaccharidedegrading machinery of this bacterium. A total of 50 proteins potentially involved in hemicellulose hydrolysis 
were screened for activity on numerous substrates, including hemicellulosic polysaccharides and related oligosaccharides, as well as various aryl-glycosides. We characterised the most promising enzymes for biotechnological applications and present a set of new enzymes for the degradation of xylan, xyloglucan, mannan, galacto- and glucomannan, arabinan, and galactan. The presented enzymes may function as a technology platform for utilisation of these polysaccharides through modification, partial or complete degradation.

\section{Methods}

\section{Preparation of secreted $C$. stercorarium proteins}

Culture supernatants were prepared from C. stercorarium cells grown on filter paper or oat spelt xylan as carbon source $(5 \mathrm{~g} / \mathrm{L})$ in $500 \mathrm{~mL}$ GS2 medium until substrate depletion. The main culture was inoculated with $25 \mathrm{~mL}$ of a 50-mL starter culture [36]. Extracellular protein was precipitated from clarified culture with ammonium sulfate as described by Koeck et al. and resuspended in $15 \mathrm{~mL}$ saturated $\left(\mathrm{NH}_{4}\right)_{2} \mathrm{SO}_{4}$ solution [37]. For enzymatic assays, $2 \mathrm{~mL}$ suspension was centrifuged $(16,000 \mathrm{~g}, 20 \mathrm{~min})$ and precipitated protein was dissolved in $200 \mu \mathrm{L} 0.1 \mathrm{M}$ MOPS reaction buffer ( $\mathrm{pH}$ 6.5, $50 \mathrm{mM} \mathrm{NaCl}, 10 \mathrm{mM} \mathrm{CaCl}_{2}$ ). Protein concentration was determined by using a Bradford Protein Assay kit (Thermo Fisher Scientific).

\section{Cloning, expression, and purification of recombinant enzymes}

Glycoside hydrolases (GH) of interest were identified using the classification of the Carbohydrate-Active Enzymes database (CAZy) $[8,38]$. Genes encoding putative hemicellulolytic glycoside hydrolase families were amplified from genomic DNA of $C$. stercorarium DSM 8532 (NC_020134.1) and cloned into pET-24c(+) vectors (Merck) using the Gibson assembly method (primer list in Additional file 1: Table S1) [15, 39, 40]. Genes were cloned without predicted $\mathrm{N}$-terminal signal peptides (SignalP 4.1 server, default cutoff: 0.3 ) and fused to a C-terminal $\mathrm{His}_{6}$-tag for protein purification by immobilised metal ion affinity chromatography (IMAC) [4143]. Enzyme production was realised in Escherichia coli BL 21 Star $^{\mathrm{TM}}$ using ZYP-5052 auto-induction medium [44]. Protein production and protein purification were accomplished as described by Mechelke et al. [45]. After purification of the recombinant proteins by IMAC, remaining $E$. coli proteins were removed by heat denaturation $\left(55^{\circ} \mathrm{C}, 15 \mathrm{~min}\right)$. During the purification, samples were taken to confirm the size and purity of the proteins by sodium dodecyl sulfate-polyacrylamide gel electrophoresis (SDS-PAGE) [46]. The ExPASy ProtParam tool was used to calculate the extinction coefficient and the molecular weight of the purified recombinant enzyme $[47,48]$.

\section{Proteome analysis of intra- and extracellular glycoside hydrolases}

We employed a quantitative mass spectrometry-based proteomics strategy to identify secreted and intracellular proteins of C. stercorarium. C. stercorarium was grown in $50 \mathrm{~mL}$ GS2 medium with $0.5 \% \mathrm{w} / \mathrm{v}$ cellobiose until early logarithmic phase. Bacterial cells were harvested by centrifugation $\left(5000 \mathrm{~g}, 15 \mathrm{~min}, 4{ }^{\circ} \mathrm{C}\right)$. The cell pellet was resuspended in $5 \mathrm{~mL} 20 \mathrm{mM}$ MES buffer (pH 6.5). Extracellular protein was precipitated overnight as described above. The precipitate was resuspended in $150 \mu \mathrm{L}$ supernatant. Proteins were isolated and digested as described by Hornburg et al. [49]. Peptides were desalted on C18 StageTips as described previously and subjected to LC MS/MS analysis [50].

LC-MS/MS: The peptides were separated via a nano HPLC (Thermo Fisher Scientific) employing a C18 column. The HPLC was directly coupled to quadrupoleOrbitrap mass spectrometer via a nano electrospray ion source ( $Q$ Exactive ${ }^{\mathrm{TM}}$, Thermo Fisher Scientific). HPLC and Q Exactive ${ }^{\mathrm{TM}}$ were operated as described previously $[49,50]$.

We processed the MS raw data with MaxQuant (v. 1.3.8.2) [51]. MS/MS spectra were searched against the $C$. stercorarium database containing 2688 forward entries as well as a list of common contaminants included in MaxQuant. Enzyme specificity was set to trypsin allowing cleavage $\mathrm{N}$-terminally to proline and up to two miscleavages. The minimum length for peptides to be considered for identification was set to seven amino acids. Carbamidomethylation was defined as a fixed modification, and acetylation (N-terminus) and methionine oxidation were set as variable modifications. As false discovery rate (FDR) a cutoff of $1 \%$ was applied at the peptide and protein level. The median of replicates for protein length normalised $\log 2$ protein intensities (termed iBAQ values in MaxQuant) were used to compare protein abundances.

\section{Enzymatic activity and optimal reaction conditions}

Activity determination was performed with para-nitrophenyl ( $p \mathrm{NP}$ ) glycosides and polysaccharide substrates (Additional file 1: Table S2). To determine their activity, the recombinant enzymes were incubated with $4 \mathrm{mM}$ each of the $12 p \mathrm{NP}$-glycosides. In a first qualitative examination, reactions were performed with $10 \mathrm{mg} / \mathrm{L}$ enzyme overnight $(18 \mathrm{~h})$. Determined activities were quantified with $0.05-10 \mathrm{mg} / \mathrm{L}$ enzyme and reaction times between $5 \mathrm{~min}$ and $2 \mathrm{~h}$. All reactions were carried out at $60{ }^{\circ} \mathrm{C}$ and $\mathrm{pH} 6.0$ in a total volume of $50 \mu \mathrm{L}$ or $500 \mu \mathrm{L}$ using standard reaction buffer (100 mM MOPS, $\mathrm{pH} 6.5$ at room 
temperature, $50 \mathrm{mM} \mathrm{NaCl}, 10 \mathrm{mM} \mathrm{CaCl}_{2}$ ). The reaction was stopped by addition of two volumes of $1 \mathrm{M} \mathrm{Na}_{2} \mathrm{CO}_{3}$ and absorption of $p \mathrm{NP}$ was measured at $405 \mathrm{~nm}$. Activity was calculated by comparison to $p \mathrm{NP}$ as standard.

The hemicellulolytic activity of secreted or recombinantly produced enzymes was determined by measuring the increase of reducing groups caused by polysaccharide hydrolysis with the 3,5-dinitrosalicylic acid (DNSA) assay [52]. One unit (U) of enzymatic activity was defined as the amount of enzyme releasing $1 \mu \mathrm{mol}$ of xylose equivalent per minute and was calculated using xylose as standard. Reactions were performed in a total volume of $150 \mu \mathrm{L}$ in 96-well PCR plates with $0.5 \% \mathrm{w} / \mathrm{v}$ polysaccharide substrate, except for glucomannan $(0.125 \%)$ and Avicel (0.25\%). After incubation, the reaction mixture was centrifuged $\left(1100 g, 5 \mathrm{~min}, 4{ }^{\circ} \mathrm{C}\right)$ and reducing sugars were determined in a $50-\mu \mathrm{L}$ sample. For qualitative activity determination, $5 \mathrm{mg} / \mathrm{L}$ of secreted protein or recombinant enzyme was incubated with the polysaccharides in standard reaction buffer at $\mathrm{pH} 6.5$ and $60{ }^{\circ} \mathrm{C}$ for $16 \mathrm{~h}$. Quantitative determination of the enzyme activity was realised using selected polysaccharides with $0.05-24 \mathrm{mg} / \mathrm{L}$ of recombinant enzyme and reaction times between $30 \mathrm{~min}$ and $2 \mathrm{~h}$. The $\mathrm{pH}$ dependence of enzyme activity was determined in $100 \mathrm{mM}$ citrate-phosphate buffer (citric acid, $\mathrm{Na}_{2} \mathrm{HPO}_{4}, 50 \mathrm{mM} \mathrm{NaCl}$ ) with $\mathrm{pH}$ between $\mathrm{pH} 4.0$ and $\mathrm{pH} 8.0\left(\mathrm{pH}\right.$ at $\left.60{ }^{\circ} \mathrm{C}\right)$ in steps of 0.5 at $60{ }^{\circ} \mathrm{C}$. Temperature dependence of enzyme activity was also determined in $100 \mathrm{mM}$ citrate-phosphate buffer at each enzyme's optimal pH. 10 different points were measured over a temperature gradient spanning $30{ }^{\circ} \mathrm{C}$. The gradient was chosen depending on the temperature optimum of the enzyme. For the determination of the specific activity of the enzymes, hydrolysis was performed in $100 \mathrm{mM}$ MOPS buffer $(50 \mathrm{mM} \mathrm{NaCl}, 10 \mathrm{mM}$ $\left.\mathrm{CaCl}_{2}\right)$ at $\mathrm{pH} 6.0$ or $6.5(\mathrm{Abn} 43 \mathrm{~A})$ and optimal temperature. All enzymatic assays were performed in triplicate using a xylose calibration curve.

\section{Substrate specificity on oligosaccharides \\ Selected enzymes involved in xylan deg-} radation were incubated with xylopentaose $\left(\mathrm{X}_{5}\right)$ and a number of arabinoxylan oligosaccharides (AXOS): $3^{2}-\alpha-\mathrm{L}$-arabinofuranosyl-xylobiose $\left(\mathrm{A}^{3} \mathrm{X}\right), \quad 2^{3}-\alpha-\mathrm{L}$-arabinofuranosyl-xylotriose $\quad\left(\mathrm{A}^{2} \mathrm{XX}\right)$, $2^{3}, 3^{3}$-di- $\alpha$-L-arabinofuranosyl-xylotriose $\quad\left(\mathrm{A}^{2+3} \mathrm{XX}\right)$, $2^{3}, 3^{3}$-di- $\alpha$-L-arabinofuranosyl-xylotetraose $\quad\left(\mathrm{XA}^{2+3} \mathrm{XX}\right)$, $3^{3}-\alpha$-L-arabinofuranosyl-xylotetraose $\left(\mathrm{XA}^{3} \mathrm{XX}\right)$, and a mixture of $\mathrm{XA}^{3} \mathrm{XX}$ and $2^{3}-\alpha-\mathrm{L}$-arabinofuranosyl-xylotetraose $\left(\mathrm{XA}^{2} \mathrm{XX}\right)$ (Megazyme). Hydrolysis was performed overnight at optimal $\mathrm{pH}$ and temperature of each enzyme, with $2 \mathrm{mg} / \mathrm{L}$ enzyme and $20 \mathrm{mg} / \mathrm{L}$ oligosaccharide or oligosaccharide mixture in $500 \mu \mathrm{L}$ volume. The degradation products were analysed using high-performance anionexchange chromatography with pulsed amperometric detection (HPAEC-PAD) as described by Mechelke et al. [45].

\section{Chromatographic analysis of poly- and oligosaccharide hydrolysates}

Analysis of poly- and oligosaccharide hydrolysis products was carried out with thin-layer chromatography (TLC) or high-performance anion-exchange chromatography with pulsed amperometric detection (HPAEC-PAD). Hydrolysates were centrifuged $(16,000 \mathrm{~g}, 10 \mathrm{~min})$ prior to analysis. The volume for $1 \mu \mathrm{g}$ xylose equivalent, determined by DNSA assay, was separated by TLC as described by Zverlov et al. [53]. Analysis with HPAEC-PAD was performed with an ICS 3000 Dionex system (Thermo Fisher Scientific) equipped with a CarboPac ${ }^{\mathrm{TM}}$ PA1 column and a linear sodium acetate $(\mathrm{NaOAc})$ gradient as described by Mechelke et al. [45]. Hydrolysates were diluted tenfold with double-distilled water and supplemented with $2 \mathrm{mg} / \mathrm{L}$ D-mannitol as internal standard (ISTD). Degradation products were identified by comparing them to a number of monosaccharide $(2 \mathrm{mg} / \mathrm{L})$ and oligosaccharide $(10 \mathrm{mg} / \mathrm{L})$ standards: arabinose (A), xylose $(\mathrm{X})$, xylobiose $\left(\mathrm{X}_{2}\right)$, -triose $\left(\mathrm{X}_{3}\right)$, -tetraose $\left(\mathrm{X}_{4}\right)$, -pentaose $\left(\mathrm{X}_{5}\right)$, and arabinoxylooligosaccharides (AXOS) as listed above.

\section{Results}

Hemicellulose-degrading potential of the extracellular enzymes of $C$. stercorarium

The hemicellulose-degrading capabilities of C. stercorarium derive from the glycoside hydrolases secreted by the bacterium into the extracellular environment (secretome). To determine their activity, secreted proteins were prepared from $C$. stercorarium grown on oat spelt xylan or filter paper. Both protein preparations displayed activities on 15 of 26 screened polysaccharides (Fig. 1). The highest activity, not only for the xylan preparation but also for the filter paper preparation, was found with xylan substrates such as wheat arabinoxylan (medium viscosity), birch wood xylan, and oat spelt xylan.

The activity on insoluble wheat arabinoxylan was $60 \%$ lower than on soluble wheat arabinoxylan (set to 100\%). Compared with their xylanolytic activity the secreted enzymes had merely low activity on glucomannan, various galactans, xyloglucan, and polygalacturonic acid. Interestingly, the xylan protein preparation displayed higher relative activity on mixed linkage glucans, especially on barley $\beta$-glucan (79\%) and pullulan (24\%), compared to the enzyme preparation from filter paper medium (57\% and 5\%). While the determined activity of the xylan protein preparation was higher for mixed 


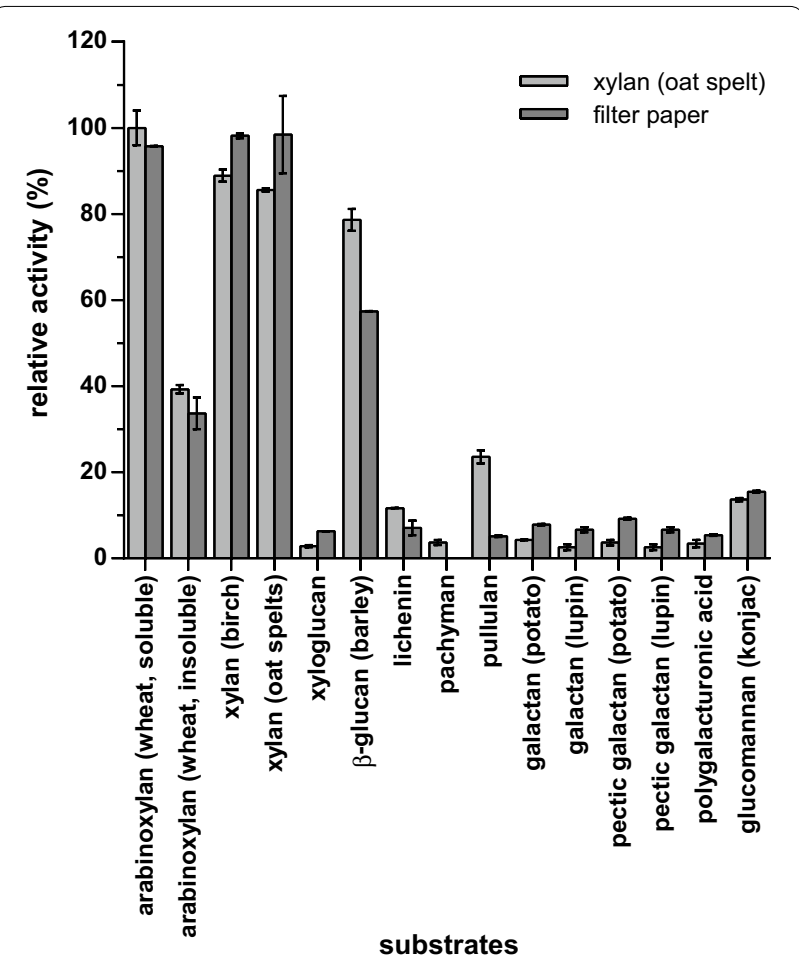

Fig. 1 Relative activity of the secreted enzymes of C. stercorarium grown on oat spelt xylan (light grey) or filter paper (dark grey). Enzymatic activity was determined by DNSA-based assay. $5.0 \mathrm{mg} / \mathrm{L}$ extracellular enzymes, precipitated from the culture supernatant, were incubated with $0.5 \%(\mathrm{~W} / \mathrm{v})$ polysaccharide at $\mathrm{pH} 6.5$ and $60^{\circ} \mathrm{C}$ in $0.1 \mathrm{M}$ MOPS reaction buffer overnight (16 h). Hydrolytic activity from oat spelt xylan medium on soluble wheat arabinoxylan was set to $100 \%$. Tested polysaccharides with no activity were: arabinan, arabinogalactan (larch), curdlan, galactomannan (guar), gum arabic (acacia), inulin (dhalia tubers), laminarin, mannan, mannan (ivory nut), rhamnogalacturonan I, sinistrin

linkage glucans, the protein preparation from filter paper appeared to be more active on birch and oat spelt xylan. C. stercorarium grew significantly faster and to a higher optical density in medium with oat spelt xylan and produced a 3.1-fold higher amount of precipitated protein (3.62 mg/L vs. $1.17 \mathrm{mg} / \mathrm{L})$. The polysaccharide substrates for the activity screening of the single recombinant enzymes were selected based on the determined activities of the extracellular enzymes.

\section{Selection of hemicellulolytic enzymes}

The Carbohydrate-Active Enzymes database (CAZy) lists 71 proteins with glycoside hydrolase $(\mathrm{GH})$ modules for C. stercorarium, distributed over $34 \mathrm{GH}$ families $[8,38]$. Based on their predicted activities, 24 typical hemicellulolytic GH families were selected and 50 genes containing modules of these $\mathrm{GH}$ families were heterologously expressed in $E$. coli for further investigation. Nineteen enzymes of $10 \mathrm{GH}$ families were excluded, because enzymes of these $\mathrm{GH}$ families require $\mathrm{NAD}+(\mathrm{GH} 4)$, are mostly parts of starch (GH13, GH15), chitin (GH18), peptidoglycan (GH23), and cellulose degradation (GH48), or act as phosphorylases. Two enzymes of GH family 36 , usually $\alpha$-galactosidases, were also excluded (Additional file 1: Table S3).

All 50 proteins were successfully cloned, produced and purified in intact form (Table 1, Additional file 1: Figure S1). The amount of purified protein ranged from $1.8 \mathrm{mg} / \mathrm{L}$ E. coli culture for BglA to $253.0 \mathrm{mg} / \mathrm{L}$ for Bxl39A. One protein, the endo- $\beta-1,4$-galactanase Gal53A was produced in a shortened version with only 909 amino acids (AA) instead of the complete 1784 AA, because the full-length gene could not be cloned into the pET-24c(+) expression vector. PCR oligonucleotide primer was designed to bind $1296 \mathrm{bp}$ behind the $5^{\prime}$ end and $1329 \mathrm{bp}$ in front of the $3^{\prime}$ end of the galA gene to include the complete GH53 module while excluding the S-layer homology modules (Additional file 1: Figure S2). Signal peptides, with lengths between $13 \mathrm{AA}$ and $34 \mathrm{AA}$, were predicted for 11 proteins, of which 10 were present in the secretome of $C$. stercorarium [43]. The enzyme Axh43A was detected neither in the secretome nor in the intracellular proteome.

Thirty-two of the 50 investigated proteins showed hydrolytic activity on polysaccharides or $p \mathrm{NP}$-glycosides among the substrates tested. No activity could be found for proteins containing modules of GH family 27 , $28,29,38,67,88,95,115$, or 127 , two proteins containing a GH3 module, four proteins containing a GH105 module, and one protein with a non-classified GH module. Proteins which were characterised for the first time were named according to their main activity described herein, as was suggested by Schwarz et al. [54]. Schematic module structures of the examined proteins are given in Additional file 1: Figure S1. Seven proteins contained additional carbohydrate-binding modules (CBM) that are predicted to bind to polysaccharides, promoting the enzymatic degradation of insoluble polysaccharides [55].

\section{Glycoside hydrolases in the secretome and intracellular proteome of $C$. stercorarium}

To examine if the heterologously produced enzymes of this study are also produced by $C$. stercorarium, the secretome and intracellular proteome of C. stercorarium were analysed by mass spectrometry (Additional file 1: Table S4, Additional file 2). The proteome analysis revealed 46 proteins produced by $C$. stercorarium, showing that these proteins may have a biological relevance in the organism. C. stercorarium did not produce the four enzymes Axh43A, Xyn105F, BglA, and AGC67892.1, at least when cultivated on cellobiose as carbon source. 
Table 1 List of investigated glycoside hydrolases of C. stercorarium

\begin{tabular}{|c|c|c|c|c|}
\hline Accession number & Protein name & Modules & SP & Lit. \\
\hline AGC67981.1 & Bga2B & $\mathrm{GH} 2$ & - & \\
\hline AGC67186.1 & $\mathrm{Bga} 2 \mathrm{E}$ & $\mathrm{GH} 2$ & - & \\
\hline AGC67268.1 & Bga2D & $\mathrm{GH} 2$ & - & \\
\hline AGC67637.1 & $\mathrm{Bga} 2 \mathrm{C}$ & $\mathrm{GH} 2$ & - & \\
\hline AGC68382.1 & $\operatorname{Uid} 2 \mathrm{~A}$ & $\mathrm{GH} 2$ & - & \\
\hline AGC67275.1 & $\mathrm{B} \times 13 \mathrm{~B}$ & $\mathrm{GH} 3$ & - & [17] \\
\hline AGC67337.1 & Bgl3Z & $\mathrm{GH} 3$ & - & [17] \\
\hline AGC67350.1 & - & $\mathrm{GH} 3$ & - & \\
\hline AGC68204.1 & - & $\mathrm{GH} 3, \mathrm{CBM} 6$ & - & \\
\hline AGC68338.1 & Nag3A & $\mathrm{GH} 3$ & $22 \mathrm{AA}$ & \\
\hline AGC68873.1 & Cel9z & $\mathrm{GH} 9,2 \times \mathrm{CBM} 3,2 \times \mathrm{CBM} \times 2$ & $27 \mathrm{AA}$ & {$[19,20]$} \\
\hline AGC67515.1 & Xyn10E & $\mathrm{GH} 10$ & - & \\
\hline AGC67677.1 & Xyn10C & GH10, CBM9, $2 \times$ CBM22 & $29 \mathrm{AA}$ & {$[17,25]$} \\
\hline AGC67715.1 & Xyn10B & $\mathrm{GH} 10$ & $34 \mathrm{AA}$ & {$[17,24]$} \\
\hline AGC67759.1 & Xyn10D & $\mathrm{GH} 10$ & - & \\
\hline AGC68909.1 & Xyn11A & $\mathrm{GH} 11,3 \times \mathrm{CBM} 6$ & $30 \mathrm{AA}$ & {$[17,23]$} \\
\hline AGC68130.1 & $\operatorname{Man} 26 \mathrm{~A}$ & GH26, CBM35 & $26 \mathrm{AA}$ & \\
\hline AGC68671.1 & - & $\mathrm{GH} 27$ & - & \\
\hline AGC67830.1 & - & $\mathrm{GH} 28$ & - & \\
\hline AGC67947.1 & - & $\mathrm{GH} 28$ & - & \\
\hline AGC67128.1 & - & $\mathrm{GH} 29$ & - & \\
\hline AGC68208.1 & $\mathrm{Bx} \mid 31 \mathrm{D}$ & $\mathrm{GH} 31$ & - & \\
\hline AGC69232.1 & Bga35A & GH35 & - & \\
\hline AGC68033.1 & - & $\mathrm{GH} 38$ & - & \\
\hline AGC67890.1 & $\mathrm{B} \times 139 \mathrm{~A}$ & GH39 & - & [17] \\
\hline AGC67716.1 & Axh43A & $2 \times \mathrm{GH} 43, \mathrm{CBM} 6$ & $29 \mathrm{AA}$ & \\
\hline AGC67945.1 & Arf43A & $\mathrm{GH} 43$ & - & [17] \\
\hline AGC68110.1 & Arf43C & $\mathrm{GH} 43$ & - & \\
\hline AGC68111.1 & Abn43A & $\mathrm{GH} 43$ & $31 \mathrm{AA}$ & \\
\hline AGC67521.1 & Xy|43B & $\mathrm{GH} 43$ & - & [28] \\
\hline AGC67885.1 & Xyl43A & $\mathrm{GH} 43$ & - & {$[27]$} \\
\hline AGC69509.1 & $B \times 143 C$ & $\mathrm{GH} 43$ & - & \\
\hline AGC67626.1 & Arf51B & GH51 & - & {$[17,56]$} \\
\hline AGC68692.1 & Gal53A & $\mathrm{GH} 53,4 \times$ CBM61 & $33 \mathrm{AA}$ & \\
\hline AGC69355.1 & Agu67A & GH67 & - & {$[30]$} \\
\hline AGC68061.1 & Ram78A & $\mathrm{GH} 78$ & $13 \mathrm{AA}$ & {$[16,31]$} \\
\hline AGC69452.1 & - & GH88 & - & \\
\hline AGC67127.1 & - & GH95 & - & \\
\hline AGC68039.1 & Xyn105F & GH105 & - & \\
\hline AGC67892.1 & - & GH105 & - & \\
\hline AGC67946.1 & - & GH105 & - & \\
\hline AGC68044.1 & - & GH105 & - & \\
\hline AGC68046.1 & - & GH105 & - & \\
\hline AGC67967.1 & - & GH115 & $25 \mathrm{AA}$ & \\
\hline AGC67053.1 & - & $\mathrm{GH} 127$ & - & \\
\hline AGC67292.1 & - & $\mathrm{GH} 127$ & - & \\
\hline AGC67072.1 & RamB & GHnc & - & \\
\hline AGC68062.1 & $\mathrm{Bg} / \mathrm{A}$ & GHnc & - & \\
\hline AGC69032.1 & - & GHnc & - & \\
\hline AGC69275.1 & ArfD & GHnc & - & \\
\hline
\end{tabular}

GenBank accession number, GH family, CBMs, and predicted signal peptide (SP) are listed; enzymes with proven activity are additionally listed with protein name. CBM modules were obtained from the CAZy and the Pfam database $[8,57,58]$. Literature (Lit.) to previously characterised enzymes is indicated. Signal peptides were predicted with the SignalP 4.1 server and a default cutoff value of 0.3 [42]. GHnc Non-classified glycoside hydrolases 
The two xylanases Xyn11A and Xyn10B were completely secreted while the four proteins, Bxl31D, Arf43C, AGC67127.1, and AGC68046.1, were only present in the intracellular proteome. The endo-acting enzymes Cel9Z, Xyn11A, Xyn10C, and Xyn10B ranked among the most abundant proteins (35\%) in the secretome, while they were not detected in the intracellular proteome (Xyn11A, Xyn10B) or belonged to the 5\% (Cel9Z) and $40 \%$ (Xyn10C) least abundant proteins of the intracellular proteome. These four enzymes, as well as Gal53A and Man26A, two enzymes ranking middle in the secretome and among the $10 \%$ of most rare proteins in the intracellular proteome, are predicted to be produced with $\mathrm{N}$-terminal signal peptides and, therefore, can be regarded as secretory proteins. This indicates that $C$. stercorarium has an effective secretion system for endo-acting glycoside hydrolases, especially for the most important xylanases. Although 32 of the studied proteins do not appear to have a signal peptide, they were found in the secretome. This might be due to the release of proteins from cells by cell lysis or to alternative secretion pathways.

\section{Activity of hemicellulolytic enzymes on $p$ NP-glycosides and polysaccharides}

The activity screenings revealed 20 new C. stercorarium glycoside hydrolases which are here characterised the first time, including three enzymes with non-classified, possibly new GH modules. The recombinant enzymes exhibited activities for the same polysaccharides as the secretome, except for pachyman, pullulan, and polygalacturonic acid, and in addition, the enzymes Abn43A and Man26A hydrolysed arabinan and mannans, respectively. One enzyme with a GH105 module, Xyn105F, displayed xylanase activity, which is the first description of this activity for GH family 105.

In activity screenings with $p$ NP-glycosides, 27 of the 32 enzymes with determined activity were able to hydrolyse the glycosidic bond in one or more of the artificial substrates. The assay revealed three $\alpha-\mathrm{L}-$ arabinofuranosidases (Arf51B, Arf43C, ArfD), two $\beta$-Dglucosidases (BglA, Bgl3Z), three $\beta$-D-galactosidases (Bga2C, Bga2D, Bga2E), two $\alpha$-L-rhamnosidases (Ram78A, RamB), seven $\beta$-D-xylosidases (Arf43A, Bxl39A, Bxl3B, Bxl43C, Bxl31D, Xyl43A, Xyl43B), one $\beta$-D-glucuronidase (Uid2A), and one $N$-acetyl- $\beta$-Dglucosaminidase (Nag3A), which showed their main activities towards $p$ NP-glycosides (Table 2). Arf51B showed by far the highest activity of all studied enzymes, $208 \mathrm{U} / \mathrm{mg}$ for $p \mathrm{NP}-\alpha$-L-arabinofuranoside, followed by the activity of Bgl3Z for $p$ NP- $\beta$-D-glucopyranoside $(19.7 \mathrm{U} / \mathrm{mg})$. More than half of the enzymes had side activities for further $p$ NP-glycosides. The xylanases Xyn10D, Xyn10E, and Xyn105F, the arabinanase
Abn43A, and the enzymes RamB and Xyl43A showed insignificant activities under the employed standard assay conditions. In a further assay the cell extract of $E$. coli producing RamB was incubated overnight with $p$ NP$\alpha$-L-rhamnopyranoside at three different temperatures. Whereas the activity of the RamB preparation proved to be low at $60{ }^{\circ} \mathrm{C}(0.04 \mathrm{U} / \mathrm{mg})$, it was 2.3 -fold $(0.10 \mathrm{U} /$ $\mathrm{mg})$ and 9.7 -fold higher $(0.43 \mathrm{U} / \mathrm{mg})$ at $55^{\circ} \mathrm{C}$ and $50{ }^{\circ} \mathrm{C}$, respectively.

An overnight screening with 29 different polysaccharides at $60{ }^{\circ} \mathrm{C}$ showed that 17 of the studied enzymes catalyse the release of reducing sugars from 16 of the polysaccharides. The enzymes containing modules of the GH families 2, 3, 9, 10, 11, 26, 35, 43, 51, 53, or 105 hydrolysed either one or more of the xylan, glucan, galactan, and mannan-based polysaccharides, and xyloglucan. Further analysis of the hydrolytic products by TLC identified the enzymes as two $\beta$-D-galactosidases (Bga35A, Bga2B), two $\beta$-D-xylosidases (Bxl3B, Arf43A), one endo-glucanase (Cel9Z), six xylanases (Xyn11A, Xyn10B, Xyn10C, Xyn10D, Xyn10E, Xyn105F), one mannanase (Man26A), one arabinoxylan arabinofuranohydrolase (Axh43A), two $\alpha$ - $\mathrm{L}$-arabinofuranosidases (Arf51B, Arf43C), one arabinanase (Abn43A), and one endo-galactanase (Gal53A) (Fig. 2, Additional file 1: Figure S3).

The specific activities of the glycoside hydrolases were determined at the temperature optimum (under standard assay conditions) of each enzyme (Table 3 ). The galactanase Gal53A degrading the $\beta-(1,4)$-galactan backbone of potato galactan, lupin galactan, and potato pectic galactan released short-chain oligosaccharides, while the $\beta$-D-galactosidases were exo-acting enzymes and released galactose as the only product (Additional file 1: Figure S3). Bga35A cleaved galactose off potato and lupin galactan and pectic galactan. Bga2B, on the other hand, released galactose only from potato galactan but also cleaved off the terminal $\beta$ - $(1,2)$-linked galactose from galactosyl-xylose side chains that are attached with $\alpha$-(1,6)-linkages to the backbone glucose residues of xyloglucan.

All six xylanases acted as endo-xylanases and showed their highest specific activity for soluble wheat arabinoxylan. Xyn10B and Xyn10C, both containing a GH10 module, additionally hydrolysed the $\beta$ - $(1,3 ; 1,4)$-glucan backbone of barley $\beta$-glucan and lichenin. While the activity of Xyn10B for arabinoxylan was 4.6 times higher than that of Xyn10C, the activities for $\beta$-glucan and lichenin were nearly the same. The xylooligosaccharides released by the xylanases differ in length: Xyn10B and Xyn10C mainly produced xylose and xylobiose while Xyn11A, containing a GH11 module, mainly produced xylobiose and xylotriose. All three enzymes released a number of additional oligosaccharides during the 


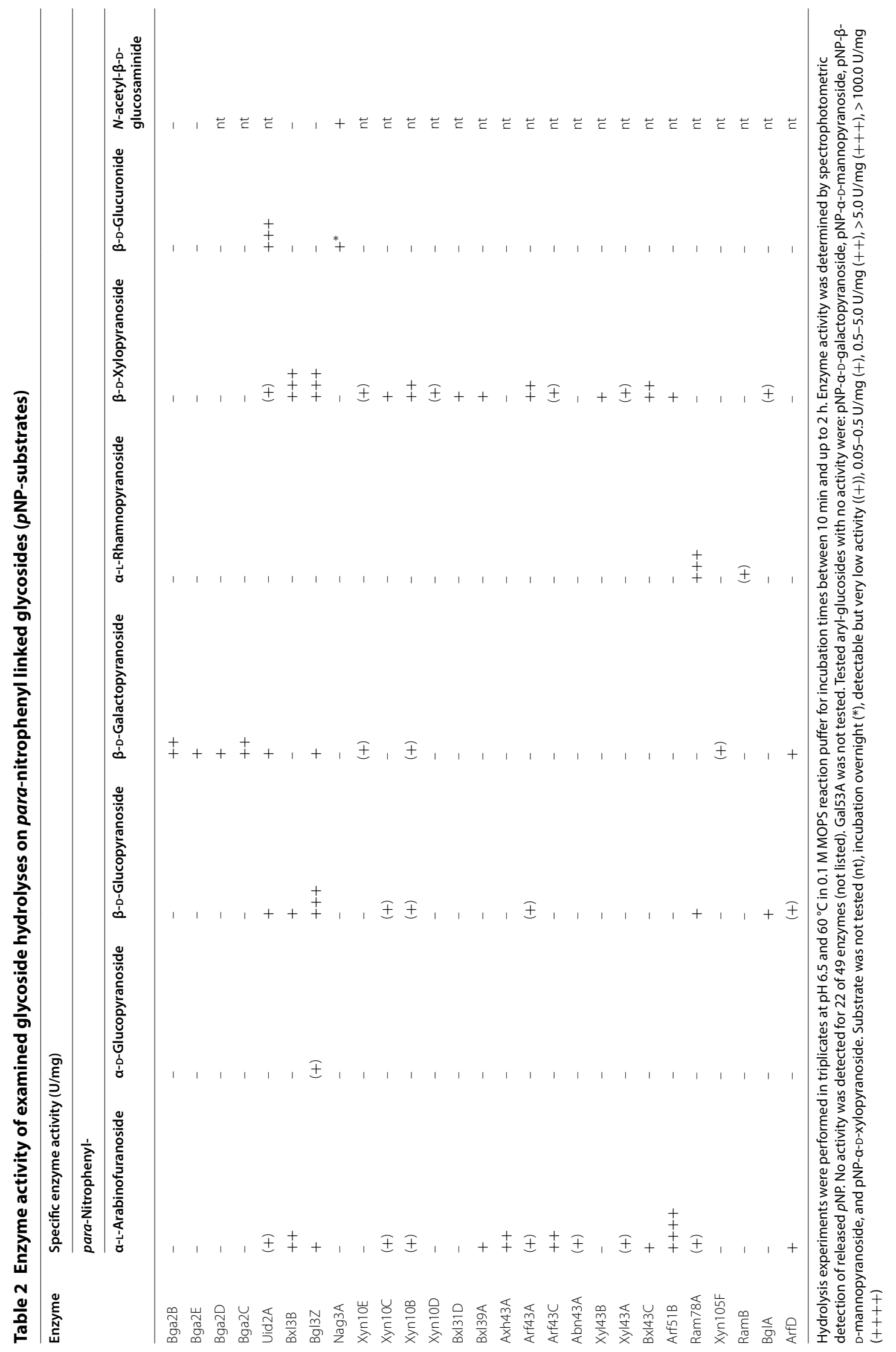




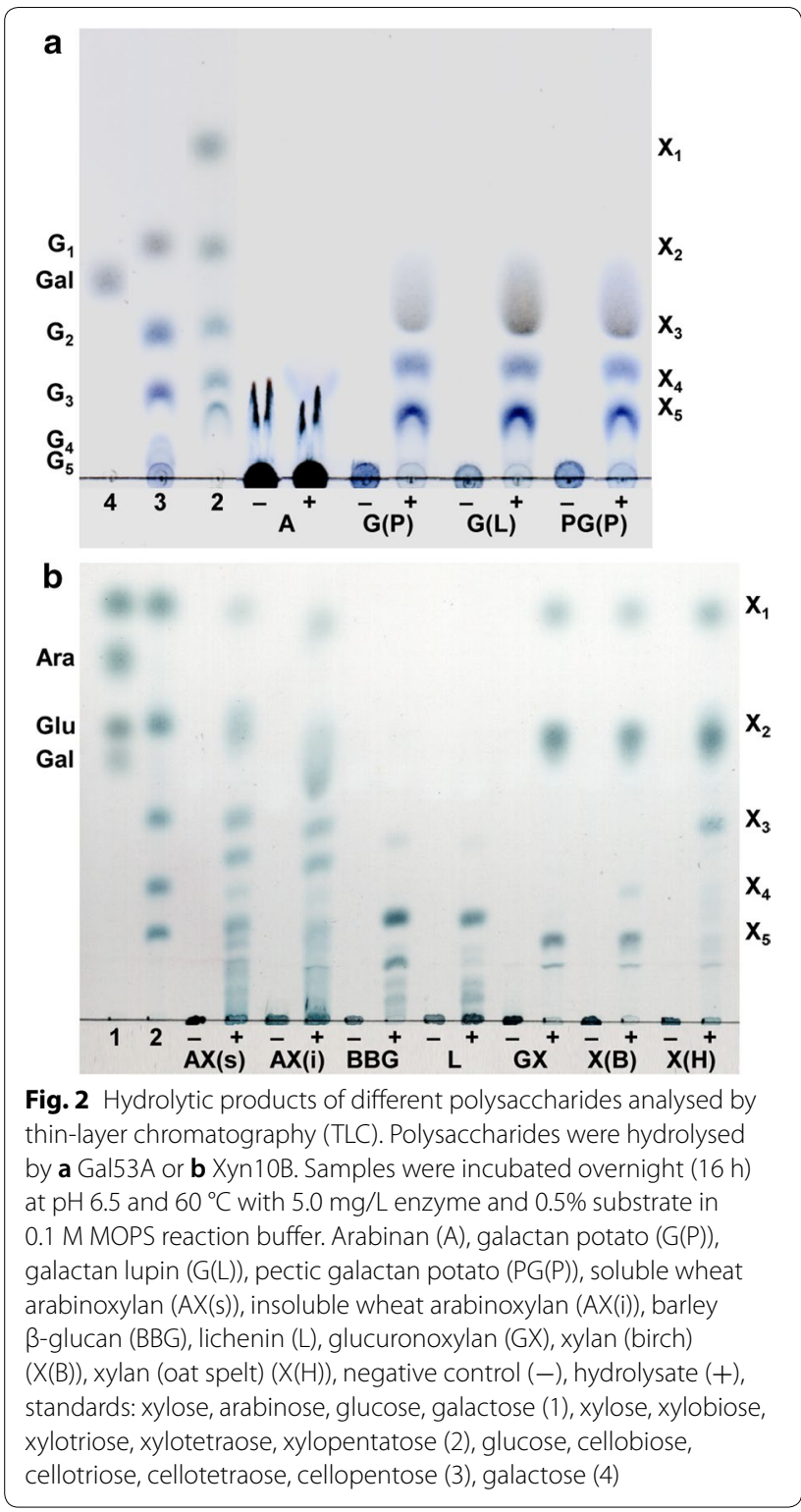

hydrolysis of arabinoxylan (Additional file 1: Figure S3). Xyn11A showed the highest specific activity (1030 U/ $\mathrm{mg}$ ), which was 1.7 times and 7.7 times higher than the specific activities of Xyn10B (597 U/mg) and Xyn10C (134 U/mg), respectively. The xylanases Xyn10D, Xyn10E, and Xyn105F also degraded xylan, but no activity was determined with $\beta$-glucan.

Cel9Z hydrolysed barley $\beta$-glucan and lichenin to oligosaccharides and degraded the backbone of glucomannan, which is composed of $\beta$ - $(1,4)$-linked D-mannose and $D$-glucose. The arabinanase Abn43A cleaved the $\alpha-(1,5)-$ linked backbone of arabinan and released arabinose from galactan and pectic galactan. Three enzymes, Arf51B, Arf43C, and Axh43A, liberated arabinose from arabinan.
Arf51B and Axh43A in addition released arabinose from soluble wheat arabinoxylan, and Arf43C released arabinose from galactan and pectic galactan. While Arf51B showed the highest specific activity for arabinan, Axh43A displayed the highest activity for arabinoxylan and only a low activity for arabinan. Arf43C showed the highest activity for potato pectic galactan. The mannanase Man26A degraded the $\beta-(1,4)$-linked backbones of mannan, galactomannan and glucomannan. In general, the determined activities for the exo-acting enzymes Axh43A, Arf43A, Arf51B, Arf43C, Bxl3B, Bga35A, and Bga2B, were significantly lower than for endo-acting enzymes.

\section{Biochemical characterisation of hemicellulolytic enzymes} The $\mathrm{pH}$ and temperature optima of 13 selected enzymes from C. stercorarium with promising hemicellulolytic activities were determined. All enzymes preferred a slightly acidic $\mathrm{pH}$ and showed the highest activity between $\mathrm{pH} 5.0$ and $\mathrm{pH} 6.5$. While the $\mathrm{pH}$ optima were nearly identical, the temperature optima differed significantly and ranged from 49 to $81{ }^{\circ} \mathrm{C}$ (Table 4). Eleven enzymes displayed maximum activity at optimal $\mathrm{pH}$ between 57 and $76{ }^{\circ} \mathrm{C}$. The highest temperature optimum of $81{ }^{\circ} \mathrm{C}$ was observed for the extracellular Cel9Z, whereas the lowest temperature optimum at $49{ }^{\circ} \mathrm{C}$ was found with the intracellular Arf43C. The four xylanases were all most active above $65{ }^{\circ} \mathrm{C}$, with $\mathrm{Xyn} 10 \mathrm{~B}$ as the enzyme with the highest temperature optimum at $76{ }^{\circ} \mathrm{C}$ (Fig. 3). The temperature range in which the activity exceeded $60 \%$ of the maximum activity was between 8 and $30{ }^{\circ} \mathrm{C}$, with Bga2B and Arf51B displaying more than $60 \%$ activity over a $30^{\circ} \mathrm{C}$ wide temperature range.

\section{Substrate specificity and activity on oligosaccharides}

The secreted proteins of $C$. stercorarium displayed the highest activity for wheat arabinoxylan and several of the recombinant proteins were specific for wheat arabinoxylan. In order to determine the substrate specificity of the xylanases (Xyn11A, Xyn10B-D, Xyn105F), $\beta$-xylosidases (Bxl3B, Arf43A) and arabinose-releasing enzymes (Arf51B, Axh43A) in greater depth, purified xylooligosaccharides (XOS) and arabinoxylooligosaccharides (AXOS) were hydrolysed and the degradation products were analysed by HPAEC-PAD (Fig. 4). All five xylanases degraded xylopentaose first to xylotriose and xylobiose and released xylotriose and xylobiose or two xylobiose molecules and xylose as final products. Only the GH10 xylanases Xyn10B, Xyn10C, and Xyn10D were able to partially degrade certain AXOS. Xyn10B and Xyn10C hydrolysed the xylose backbone at the non-reducing end 
Table 3 Hemicellulolytic activity of seventeen glycoside hydrolases on 29 different polysaccharides

\begin{tabular}{|c|c|c|c|c|c|c|c|c|c|}
\hline \multirow[t]{2}{*}{ Enzymes } & \multicolumn{9}{|c|}{ Specific activity (U/mg) } \\
\hline & Arabinan & $\begin{array}{l}\text { Arabinoxylan } \\
\text { (wheat, soluble) }\end{array}$ & $\begin{array}{l}\text { Arabinoxylan } \\
\text { (wheat, } \\
\text { insoluble) }\end{array}$ & $\begin{array}{l}\text { 4-O-Methyl- } \\
\text { glucuron- } \\
\text { oxylan }\end{array}$ & Xylan (birch) & \multicolumn{2}{|c|}{ Xylan (oat spelt) } & Xyloglucan & $\beta$-Glucan (barley) \\
\hline Bga2B & $(+)$ & - & - & - & - & \multicolumn{2}{|l|}{ - } & $3.11 \pm 0.04$ & - \\
\hline $\mathrm{B} \times 13 \mathrm{~B}$ & - & $0.25 \pm 0.01$ & + & $0.21 \pm 0.01$ & $0.28 \pm 0.01$ & \multicolumn{2}{|l|}{$0.35 \pm 0.02$} & - & - \\
\hline Cel9Z & - & - & - & $(+)$ & - & \multicolumn{2}{|l|}{$(+)$} & - & $159 \pm 1$ \\
\hline Xyn10E & - & $0.17 \pm 0.01$ & - & + & $(+)$ & \multicolumn{2}{|l|}{$(+)$} & - & - \\
\hline Xyn10C & - & $134 \pm 5$ & $14.1 \pm 0.8$ & $91.3 \pm 3.8$ & $56.3 \pm 2.0$ & \multicolumn{2}{|l|}{$86.6 \pm 1.2$} & - & $19.1 \pm 0.1$ \\
\hline Xyn10B & - & $597 \pm 46$ & $40.4 \pm 3.7$ & $483 \pm 45$ & $185 \pm 20$ & \multicolumn{2}{|l|}{$679 \pm 41$} & - & $18.8 \pm 1.6$ \\
\hline Xyn10D & - & $6.55 \pm 0.09$ & - & + & $1.24 \pm 0.04$ & \multicolumn{2}{|l|}{$6.17 \pm 0.08$} & - & $(+)$ \\
\hline Xyn11A & - & $1030 \pm 50$ & $226 \pm 47$ & $936 \pm 19$ & $619 \pm 7$ & \multicolumn{2}{|l|}{$937 \pm 6$} & - & - \\
\hline Man26A & - & - & - & - & - & \multicolumn{2}{|l|}{-} & + & - \\
\hline Bga35A & $(+)$ & - & - & - & - & \multicolumn{2}{|l|}{-} & - & - \\
\hline Axh43A & + & $41.5 \pm 0.8$ & $(+)$ & $(+)$ & - & \multicolumn{2}{|l|}{+} & - & - \\
\hline Arf43A & - & $(+)$ & - & $(+)$ & $(+)$ & \multicolumn{2}{|l|}{$(+)$} & - & - \\
\hline Arf43C & $0.82 \pm 0.06$ & - & - & - & - & \multicolumn{2}{|l|}{-} & - & - \\
\hline Abn43A & $79.5 \pm 0.9$ & - & - & - & - & \multicolumn{2}{|l|}{-} & - & - \\
\hline Arf51B & $2.01 \pm 0.03$ & $0.32 \pm 0.01$ & - & - & - & \multicolumn{2}{|l|}{$(+)$} & - & - \\
\hline Gal53A & + & - & - & - & - & \multicolumn{2}{|l|}{-} & - & - \\
\hline Xyn105F & - & $0.22 \pm 0.01$ & - & + & + & \multicolumn{2}{|l|}{+} & - & - \\
\hline \multirow[t]{2}{*}{ Enzymes } & \multicolumn{9}{|c|}{ Specific activity (U/mg) } \\
\hline & Lichenin & Galactan (potato) & Galactan (lupin) & $\begin{array}{l}\text { Pectic } \\
\text { galactan } \\
\text { (potato) }\end{array}$ & $\begin{array}{l}\text { Pectic } \\
\text { galactan } \\
\text { (lupin) }\end{array}$ & Mannan & \multicolumn{2}{|c|}{$\begin{array}{l}\text { Galactomannan } \\
\text { (guar) }\end{array}$} & $\begin{array}{l}\text { Glucomannan } \\
\text { (konjac) }\end{array}$ \\
\hline Bga2B & - & + & $(+)$ & $(+)$ & $(+)$ & - & \multicolumn{2}{|l|}{-} & - \\
\hline $\mathrm{B} \times 13 \mathrm{~B}$ & - & - & - & - & - & - & \multicolumn{2}{|l|}{ - } & - \\
\hline Cel9Z & $136 \pm 9$ & - & - & - & - & - & - & & $32.9 \pm 1.0$ \\
\hline Xyn10E & - & - & - & - & - & - & - & & - \\
\hline Xyn10C & $7.85 \pm 0.45$ & - & - & - & $(+)$ & - & - & & + \\
\hline Xyn10B & $9.65 \pm 0.65$ & - & - & - & $(+)$ & - & - & & $(+)$ \\
\hline Xyn10D & - & - & - & - & $(+)$ & - & - & & - \\
\hline Xyn11A & - & - & - & - & - & - & - & & - \\
\hline Man26A & - & - & - & - & - & $39.9 \pm 2.0$ & $216=$ & & $144 \pm 3$ \\
\hline Bga35A & - & $2.17 \pm 0.03$ & $1.24 \pm 0.08$ & $1.08 \pm 0.01$ & $1.14 \pm 0.02$ & - & - & & - \\
\hline Axh43A & - & - & - & - & $(+)$ & - & - & & - \\
\hline Arf43A & - & - & - & - & $(+)$ & - & - & & - \\
\hline Arf43C & - & - & $1.99 \pm 0.20$ & $6.50 \pm 0.13$ & $4.46 \pm 0.09$ & - & - & & - \\
\hline Abn43A & - & - & $10.1 \pm 0.3$ & $21.3 \pm 0.2$ & $12.0 \pm 2.1$ & - & - & & - \\
\hline Arf51B & - & - & - & $(+)$ & - & - & - & & - \\
\hline Gal53A & - & + & + & + & + & + & - & & - \\
\hline Xyn105F & - & - & - & - & - & - & - & & - \\
\hline
\end{tabular}

Hydrolysis experiments were performed in $0.1 \mathrm{M}$ MOPS reaction buffer with $0.05-24 \mathrm{mg} / \mathrm{L}$ enzyme at $\mathrm{pH} 6.0$ ( $\mathrm{pH} 6.5$ for Abn43A) and the temperature optimum of each enzyme for incubation times from 30 min up to $2 \mathrm{~h}$. The specific enzyme activity was determined using DNSA assay in triplicates. Further tested polysaccharides for which no activity could be determined were: arabinogalactan (larch), curdlan, gum arabic (acacia), inulin (dahlia tubers), laminarin, mannan (ivory nut), pachyman, polygalacturonic acid, pullulan, rhamnogalacturonan I, sinistrin, chitosan and Avicel. No activity (-), detectable but very low activity $((+))$, activity overnight $(+)$, specific activity (numbers)

next to an arabinosylated xylose residue, while Xyn10D hydrolysed the reducing end of AXOS, one xylose residue next to the substituted xylose. Xyn10B released the terminal xylose from $\mathrm{XA}^{2} \mathrm{XX}, \mathrm{XA}^{3} \mathrm{XX}$, and $\mathrm{XA}^{2+3} \mathrm{XX}$, while Xyn10C was unable to hydrolyse AXOS containing $\alpha-(1,2)$-linked arabinosylations. Xyn10D cleaved off the 
Table 4 Optimal reaction conditions of 13 hemicellulolytic glycoside hydrolases

\begin{tabular}{llllll}
\hline Enzyme & $\mathbf{p H}_{\text {opt }}$ & $\mathbf{p H}$ range & $\boldsymbol{T}_{\text {opt }}\left({ }^{\circ} \mathbf{C}\right)$ & $\boldsymbol{T}_{\text {range }}\left({ }^{\circ} \mathbf{C}\right)$ & Substrate \\
\hline Bga2B & 6.0 & $5.0-6.5$ & 56.8 & $40-70$ & Xyloglucan \\
BxI3B & 5.5 & $5.0-6.5$ & 65.6 & $48-72$ & Glucuronoxylan \\
Cel9Z & 5.5 & $4.0-6.5$ & 80.6 & $66-87$ & B-Glucan (barley) \\
Xyn10C & 6.0 & $4.5-7.5$ & 70.6 & $56-77$ & Arabinoxylan \\
Xyn10B & 5.5 & $4.0-7.0$ & 75.6 & $61-79$ & Arabinoxylan \\
Xyn10D & 6.0 & $5.0-7.0$ & 65.6 & $58-66$ & Arabinoxylan \\
Xyn11A & 5.5 & $4.5-7.0$ & 66.8 & $56-74$ & Arabinoxylan \\
Man26A & 5.5 & $5.0-6.0$ & 61.8 & $48-66$ & Galactomannan \\
Bga35A & 5.5 & $5.0-6.0$ & 60.6 & $40-67$ & Galactan (lupin) \\
Axh43A & 6.0 & $5.5-6.5$ & 60.6 & $49-64$ & Arabinoxylan \\
Arf43C & 6.0 & $5.5-7.0$ & 49.4 & $43-64$ & Pectic galactan \\
& & & & & (potato) \\
Abn43A & 6.5 & $6.0-7.0$ & 65.6 & $51-72$ & Arabinan \\
Arf51B & 5.0 & $4.5-5.5$ & 61.8 & $45-75$ & Arabinan \\
\hline
\end{tabular}

The enzymes were incubated with $0.5 \%$ of the indicated substrate at $\mathrm{pH} 4.0$ to pH 8.0 (at $60^{\circ} \mathrm{C}$ ) and between $40^{\circ} \mathrm{C}$ and $90^{\circ} \mathrm{C}$ (at the enzymes' optimal pH) for $30 \mathrm{~min}, 60 \mathrm{~min}$ (Bga2B, Bga35A and Arf51B) or $120 \mathrm{~min}$ (Bxl3B). Enzyme activities were determined by DNSA-based assay in triplicates. Borders for $\mathrm{pH}$ and $T$ ranges were set to $60 \%$ of the highest activity

terminal xylose at the reducing end of all AXOS with the exception of $\mathrm{A}^{3} \mathrm{X}$.

Arf51B and Axh43A containing a GH51 and two GH43 modules, respectively, completely cleaved the $\alpha-(1,2)$ and $\alpha$-(1,3)-linked L-arabinose residue off singly and doubly substituted AXOS releasing xylooligosaccharides and arabinose. Both $\beta$-xylosidases, Bxl3B and Arf43A, sequentially degraded xylopentaose to xylose. Arf43A and $\mathrm{Bxl} 3 \mathrm{~B}$ cleaved off the terminal xylose at the nonreducing end of $\mathrm{XA}^{2} \mathrm{XX}$, but only Arf43A was able to also hydrolyse $\mathrm{XA}^{3} \mathrm{XX}$ and $\mathrm{XA}^{2+3} \mathrm{XX}$.

\section{Product specificity of the xylanases Xyn $11 \mathrm{~A}$ and Xyn10B}

To further investigate the substrate specificities (Figs. 4 and 5) and the product specificities of Xyn11A and Xyn10B, wheat arabinoxylan hydrolysate obtained after enzymatic hydrolysis was analysed by HPAEC-PAD. In agreement with the TLC results, the degradation products of arabinoxylan hydrolysed by Xyn11A and Xyn10B are XOS and AXOS. Xyn11A released xylose, xylobiose and xylotriose, while Xyn10B produced xylose and xylobiose as final products, indicating the degradation of xylotriose. The quantity of released XOS decreased with the product polymerisation degree for Xyn11A, whereas Xyn10B released xylose and xylobiose in similar quantities. Besides the liberation of XOS, Xyn10B hydrolysed wheat arabinoxylan into three known AXOS, $\mathrm{A}^{3} \mathrm{X}, \mathrm{XA}^{2+3} \mathrm{XX}$, and $\mathrm{A}^{2+3} \mathrm{XX}$. The amount of released $\mathrm{A}^{3} \mathrm{XX}$ was approximately twice as high as the amount
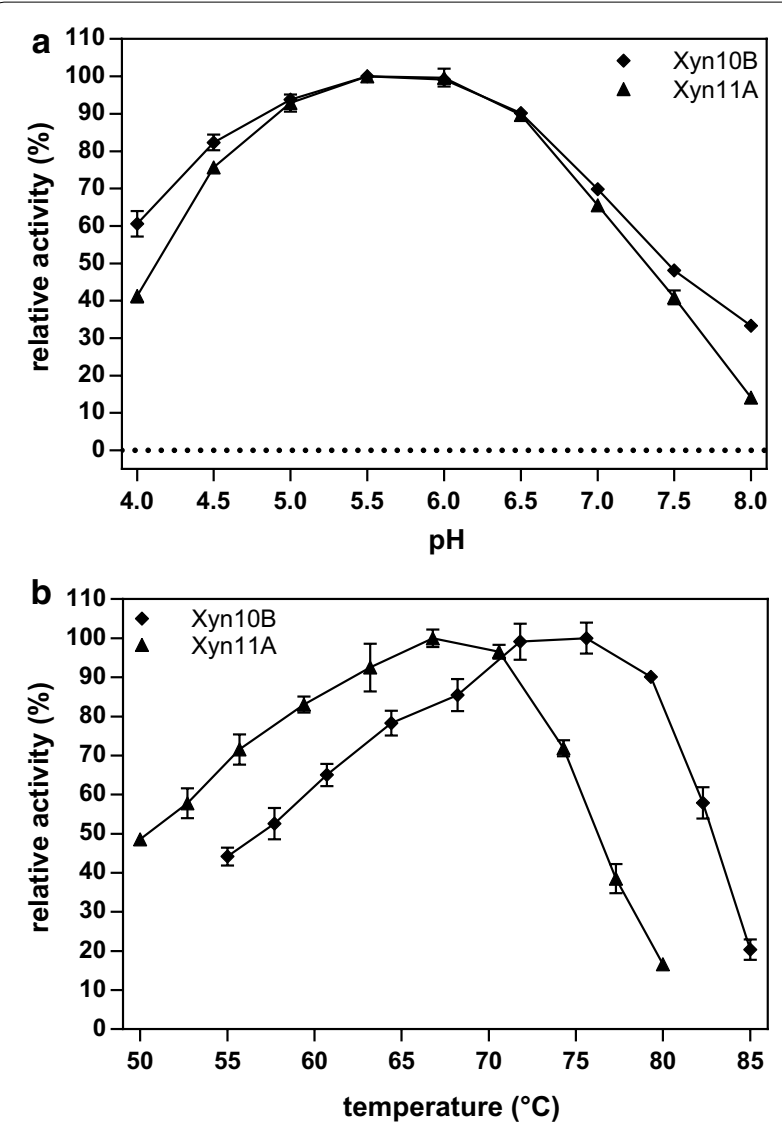

Fig. 3 Relative activity of Xyn $11 \mathrm{~A}$ and $X \mathrm{Xn} 10 \mathrm{~B}$ with $0.5 \%$ soluble arabinoxylan at different $\mathrm{pH}$ values (a) and temperatures (b).

Experiments were performed for $30 \mathrm{~min}$ at $\mathbf{a} 60^{\circ} \mathrm{C}$ or $\mathbf{b}$ at the optimal $\mathrm{pH}$ of each enzyme in $0.1 \mathrm{M}$ citrate-phosphate reaction buffer with $0.1 \mathrm{mg} / \mathrm{L}$ Xyn $10 \mathrm{~B}$ or $0.05 \mathrm{mg} / \mathrm{L}$ Xyn11A

of $X A^{2+3} X X$ and $A^{2+3} X X$. Xyn11A produced $X^{3} X X$, $\mathrm{XA}^{2+3} \mathrm{XX}, \mathrm{A}^{2+3} \mathrm{XX}$, and an unknown substance with a retention time at $43.1 \mathrm{~min}$. While $\mathrm{Xyn} 10 \mathrm{~B}$ produced more $\mathrm{A}^{2+3} \mathrm{XX}$ than $\mathrm{XA}^{2+3} \mathrm{XX}$, Xyn11A produced more $\mathrm{XA}^{2+3} \mathrm{XX}$. In total, Xyn10B released larger amounts of XOS and AXOS from wheat arabinoxylan, due to its broad substrate specificity, even though the specific activity of Xyn11A was higher.

\section{Discussion}

Hemicellulose degradation capacity of $C$. stercorarium

Utilisation of renewable biomass for the generation of fuels, electricity, and heat is a climate-friendly addition to the common energy production technologies [59]. In order to permit an energetically and economically efficient process, the degradation of the different polysaccharides in biomass should be as complete as possible. C. stercorarium, Clostridium thermocellum and 


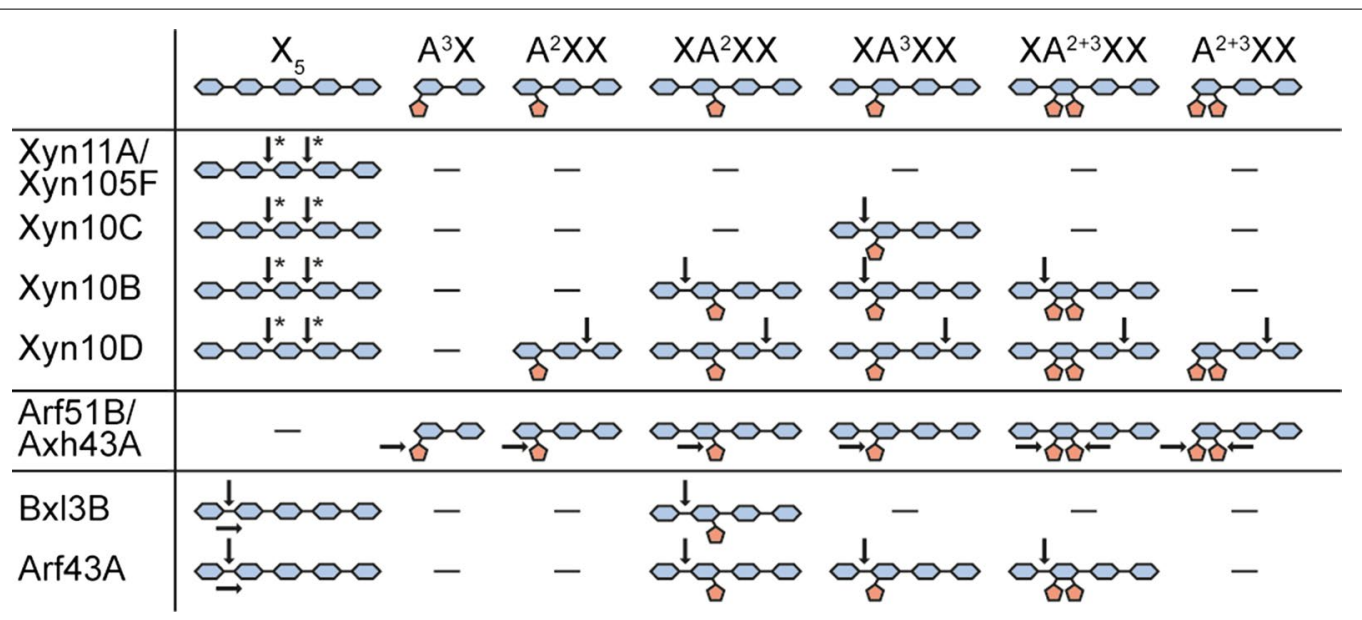

Fig. 4 Hydrolysis pattern of investigated arabinoxylanolytic enzymes on purified arabinoxylo- and xylooligosaccharides. Arrows indicate the first cleavage site of the enzymes. Arrows with asterisk indicate potential cleavage sites. Due to the design of the experiment, it was not possible to identify the actual cleavage site. The hydrolysis experiments were performed overnight at $60^{\circ} \mathrm{C}$ and pH 6.5 with $2 \mathrm{mg} / \mathrm{L}$ enzyme and $20 \mathrm{mg} / \mathrm{L}$ pure oligosaccharide or oligosaccharide mixture. Analysis of hydrolysis products was performed using HPAEC-PAD. Xylanases (Xyn), arabinofuranosidases (Arf), arabinoxylan arabinofuranohydrolase (Axh), xylosidases (Xyl)

closely related species were identified as major hydrolytic bacteria in biogas fermenters [14]. It was shown that a synthetic culture of C. thermocellum and C. stercorarium degraded $76 \%$ of maize silage and performed only slightly less effectively than the best thermophilic bacterial consortium isolated from a biogas plant [14]. Whereas $C$. thermocellum degrades and utilises cellulose with high efficiency, C. stercorarium seems to be specialised in the degradation of hemicellulose,

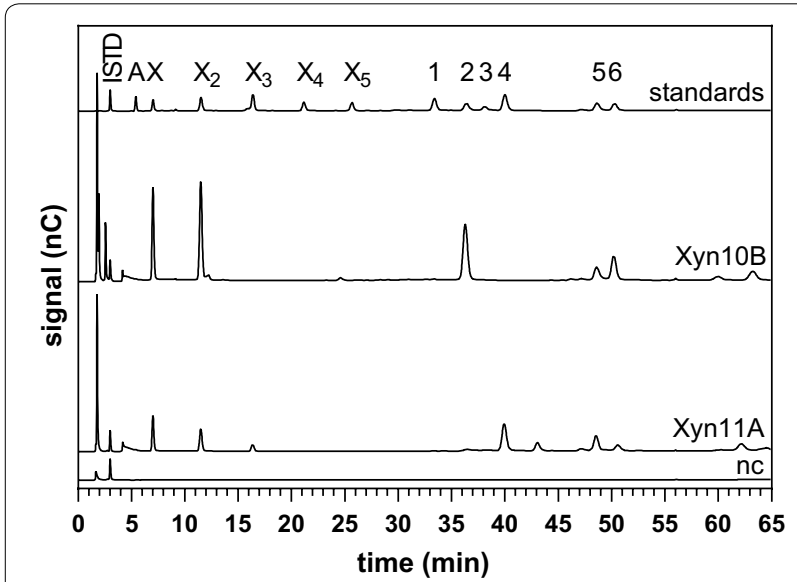

Fig. 5 Hydrolysis of $0.5 \%(w / v)$ soluble wheat arabinoxylan using Xyn $11 A$ and Xyn $10 B$ analysed by HPAEC-PAD. The experiments were performed overnight $(20 \mathrm{~h})$ at $60^{\circ} \mathrm{C}$ with $5 \mathrm{mg} / \mathrm{L} X y n 10 \mathrm{~B}$ or $X y n 11 \mathrm{~A}$. Standards: arabinose $(A)$, xylose $(X)$, xylobiose $\left(X_{2}\right)$, xylotriose $\left(X_{3}\right)$, xylotetraose $\left(X_{4}\right)$, xylopentaose $\left(X_{5}\right), A^{2} X X(1), A^{3} X(2), X A^{2} X X(3), X A^{3} X X$ (4), $X A^{2+3} X X(5), A^{2+3} X X(6)$, internal standard (ISTD), negative control (nc) since this organism harbours a great number of genes involved in the hydrolysis of hemicellulose in its genome and has the capability to utilise the degradation products, hexoses as well as pentoses [12-14].

Both preparations of extracellular proteins, precipitated from $C$. stercorarium cultures grown on oat spelt xylan or filter paper, degraded 15 of the 26 tested substrates, preferably soluble xylans and barley $\beta$-glucan (Fig. 1). The results are in accordance with a previous description of high hydrolytic activities in the culture supernatant of the type strain of $C$. stercorarium for arabinoxylan and $\beta$-glucan [12]. The significantly higher activity of the enzyme preparation obtained after growth on oat spelt xylan for mixed linkage glucans as well as the higher activity of the enzymes secreted during cultivation on filter paper for xylans are probably a result of the attachment of the major xylanases and cellulases, respectively, to xylan and cellulose. Xyn11A, Xyn10C, and Cel9Z contain CBMs that bind to the polysaccharides, decreasing the concentrations of these enzymes in the supernatant [60-62]. Although C. stercorarium grew well on both carbon sources, it grew faster on oat spelt xylan and secreted 3 times the amount of protein on this substrate, indicating a preference for xylan over filter paper.

Thirty-two of the investigated hemicellulolytic enzymes displayed polysaccharide-degrading activities when produced heterologously while no activity could be determined for the remaining 18 proteins. The reasons could be missing substrates or $\mathrm{pH}$ and temperature optima that differ significantly from the applied assay conditions 
$\left(60{ }^{\circ} \mathrm{C}, \mathrm{pH}\right.$ 6.0) as shown for RamB, which had a significantly higher activity at $50{ }^{\circ} \mathrm{C}$ than at $60^{\circ} \mathrm{C}$. The pH optimum of the previously characterised enzyme Xyn43B is $\mathrm{pH} 3.5$, while the activity of the previously characterised $\alpha$-D-glucuronidase Agu67A was not detected because the required substrates (for example: 4-O-methyl- $\alpha-\mathrm{D}-$ xylotriose) were not accessible $[28,30]$. Further enzyme activities could have passed undetected due to the limitations of the applied assay conditions or substrates. The recombinant enzymes covered the same activities as the secretome, except for pullulan, pachyman, and polygalacturonic acid and additionally displayed activities for arabinan, mannan, and galactomannan. Five GH13 enzymes, possible pullulanases, were excluded from this investigation [63].

Clostridium stercorarium has an effective secretion system for endo-acting glycoside hydrolases, especially for the most important xylanases. However, four of the proteins were apparently not present in the proteome. Whether these proteins are produced in the presence of alternative carbon sources remains to be determined.

\section{Degradation and debranching of xylans}

All xylans share a $\beta-(1,4)$-D-xylopyranose backbone, which is substituted by short glycoside and ester groups. Substitutions comprise L-arabinose (Ara), D-glucuronic acid (GlcA) or 4-O-methyl- $\alpha$-D-glucuronic acid (MeGlcA), D-xylose (Xyl), galactose, acetic acid and phenolic acid esters. Xylan in hardwood, usually referred to as 4-O-methyl-D-glucurono-D-xylan (MGX), has mainly MeGlcA substitutions attached at position $\mathrm{O}-2$ of the xylose chain with an average Xyl:MeGlcA ratio of 10:1. Arabinoxylan (AX), the major hemicellulose component in grasses and cereals, is substituted by $\alpha-\mathrm{L}-$ arabinofuranosyl residues at position $O-2$ and/or $O-3$ of the xylose monomers [5].

The apparent importance of xylans as growth substrates for C. stercorarium is reflected by its multitude of xylanases. Besides the well-characterised extracellular xylanases Xyn11A, Xyn10B, and Xyn10C, the activity screening revealed three new endo- $\beta-(1,4)$-xylanases: Xyn10D, Xyn10E, and Xyn105F. All six xylanases were most active on soluble wheat arabinoxylan. Xyn10B and Xyn10C further showed activity for mixed linkage glucans as previously reported for both enzymes [17]. Xyn11A showed a comparably high activity towards insoluble arabinoxylan due to a high specificity of the three CBM6 modules for insoluble xylan [60]. One possible explanation for the higher activity of Xyn10C for barley $\beta$-glucan compared to Xyn10B is that the CBM9 and two CBM22 modules of Xyn10C preferably bind to $\beta$ - $(1,3 ; 1,4)$-glucan [61].
The substrate and product specificities of Xyn11A and $\mathrm{Xyn} 10 \mathrm{~B}$ are in accordance with the product pattern described for GH11 and GH10 xylanases. GH11 xylanases hydrolyse only unsubstituted xylan regions producing longer XOS and AXOS, while GH10 xylanases are able to hydrolyse the xylan backbone at the non-reducing end next to an arabinosylated xylose. GH10 xylanases produce mainly xylose, xylobiose and short AXOS [45, 64]. Unlike Xyn10B, Xyn10C was unable to cleave the terminal xylose off the non-reducing end of AXOS with arabinosylations at position $O-2$. Xyn10D differed significantly and hydrolysed the second $\beta-(1,4)$-linkage behind the arabinosylation at the reducing end of AXOS. A similar hydrolytic mechanism was described for the xylanase Xyn10B of Herbinix hemicellulosilytica [45]. This highlights the specific role of different xylanases in the degradation of natural hemicelluloses.

To our knowledge, Xyn105F is the first xylanase with a GH105 module. A relatively low but significant activity was measured for soluble arabinoxylan, while Xyn105F was also active on xylopentaose, releasing xylose and xylobiose. Therefore, we discovered a new activity for GH family 105, which until now had exclusively comprised unsaturated rhamnogalacturonyl and $\beta$-glucuronyl hydrolases which also might be the main activity of Xyn105F [38, 65]. However, this activity was not determined in this study.

The $\mathrm{pH}$ and temperature optima of the four xylanases Xyn11A, Xyn10B, Xyn10C, and Xyn10D are around $\mathrm{pH}$ 5.5-6.0 and $65-76{ }^{\circ} \mathrm{C}$, in accordance with previous work $[17,66]$. The genes for Xyn11A, Xyn10B, and Xyn10C encode $\mathrm{N}$-terminal signal peptide sequences, and the proteins are extracellular xylanases, abundant in the culture supernatant. In contrast, Xyn10D and Xyn10E seem to be intracellular proteins, while Xyn105F was not produced by $C$. stercorarium under the growth conditions of this study.

Arf51B, Bxl3B, and Arf43A had little activity on xylans and showed $\alpha$-arabinofuranosidase and $\beta$-xylosidase activity towards $p$ NP-glycosides, as described previously [17]. Arf43A has previously been characterised as an $\alpha$-arabinofuranosidase. However, in this work it had higher activity towards $p$ NP- $\beta$-D-xylopyranoside and, like Bxl3B, released only xylose units from XOS and AXOS $[17,26]$. As described previously, Arf51B debranched arabinoxylan but showed a higher activity for arabinan [56]. Arf51B and Axh43A completely de-arabinosylated singly and doubly substituted AXOS, the debranching activity of Axh43A towards soluble arabinoxylan being 130 times higher. Both enzymes belong to the subclass AXHB-md 2,3 of arabinose-releasing enzymes [67]. Axh43A contains a CBM6 module that often binds to $\beta$-xylan and 
presumably enhances the debranching activity towards arabinoxylan [68].

Xylanases, $\alpha$-arabinofuranosidases, including arabinoxylan arabinofuranohydrolases, and $\beta$-xylosidases act synergistically to completely hydrolyse arabinoxylan. Adelsberger et al. [17] showed that Xyn11A or Xyn10C combined with Arf51 and Bxl3B degraded de-esterified arabinoxylan completely to its monosaccharides. We identified at least four new enzymes that are involved in the xylan degradation of $C$. stercorarium. The new enzymes and the detailed information about their substrate and product specificities are helpful for improving the reconstituted enzyme system for xylan hydrolysis. A substitution of Arf51B with Axh43A, for example, could accelerate the debranching of arabinoxylan while Xyn10B and Xyn10D are able to hydrolyse more AXOS than Xyn11A and Xyn10C.

\section{Degradation of glucan, xyloglucan, and mannan}

Mixed linkage glucans are linear polysaccharides comprised of $\beta$-(1,4)-linked D-glucose oligomers, which are separated by single $\beta$-(1,3)-linkages. Xyloglucans (XG) have a $\beta$-(1,4)-D-glucopyranose backbone branched with $\alpha-(1,6)$-D-xylopyranoside units. The xylopyranoside residues can be substituted by $\beta$-(1,2)-linked D-galactopyranose, a further xylopyranose, or other sugars $[1$, 5]. Galactoglucomannans (GGM) have a linear $\beta-(1,4)$ linked backbone comprised of $\beta$-D-glucopyranose and $\beta$-D-mannopyranose. The main polymeric chain is acetylated and substituted by $\alpha-(1,6)$-D-galactopyranosyl residues $[4,5]$. Galactomannan backbones consist exclusively of $\beta$-(1,4)-linked D-mannopyranose units and are also substituted with galactosyl residues. Slightly galactosylated (4-15\%) polymers are referred to as glucomannans and mannans [5].

The endo-glucanase Cel9Z was secreted by C. stercorarium and showed activity towards mixed linkage glucans and glucomannan. In contrast to previous characterisations, only insignificant activity towards microcrystalline cellulose (Avicel) was determined [18, 20]. The high-temperature optimum of $81{ }^{\circ} \mathrm{C}$ can partially be explained by the presence of a thermostabilising CBM3 module, while a second CBM3 module mediates the binding to crystalline cellulose [62]. The determined $\beta$-galactosidase and endo- $\beta$-mannanase activity of the newly characterised enzymes Bga2B and Man26A, respectively, are in accordance with the common activities for the GH families 2 and 26 [69]. Unlike the other newly characterised $\beta$-galactosidases Bga2C-E, Bga2B is able to hydrolyse the $\beta$-(1,2)-D-galactopyranosyl substitution of xyloglucan. Man26A contains a CBM35 module that commonly binds to mannan and mannooligosaccharides [70].

\section{Degradation of arabinan and galactan}

Arabinans and (arabino)galactans are side chains of the pectic polysaccharide rhamnogalacturonan I. In addition, $\alpha$-(1,5)-linked arabinan structures may also exist as free polymers unattached to the pectic domains [71]. Arabinans are composed of an $\alpha-(1,5)$-L-arabinofuranoside backbone branched with $\alpha-(1,2)$ - and/or $\alpha$-(1,3)-linked $\mathrm{L}$-arabinosyl oligosaccharides at position $\mathrm{O}-2$ or $\mathrm{O}-3$. Galactans are linear $\beta$-(1,4)-D-galactopyranoside polymers substituted by single $\alpha$-L-arabinofuranoside units at position $O-3$ [72, 73].

As described above, Arf51B released arabinose from arabinan, probably by cleaving off the $\alpha-(1,2)$ - and $\alpha-(1,3)$-linked arabinosylations [67]. Four new enzymes for the degradation of arabinan and galactan were characterised: Arf43C, Abn43A, Bga35A, and Gal53A. Arf43C released arabinose from arabinan and galactan, with a higher activity towards galactan, especially pectic galactan. The $\alpha$-arabinofuranosidase probably prefers or hydrolyses exclusively $\alpha-(1,3)$-arabinosylations. Abn43A showed endo- $\alpha-(1,5)$-arabinanase activity in degrading arabinan and also $\alpha-(1,3)$-arabinofuranosidase activity in debranching galactans. The activities of both enzymes are in accordance with the common activities of GH family $43[67,68]$. Abn43A and Arf43C or Arf51A combined could be sufficient to hydrolyse arabinan completely to arabinose, as described for combinations of endo-arabinanase and $\alpha$-arabinofuranosidase [67].

Gal53A showed endo- $\beta$-galactanase activity towards galactan and pectic galactan in accordance with the common activity for GH family 53 [38]. The native full-length protein contains a signal peptide, four CBM61 modules, and three S-layer homology modules. The enzyme was secreted by $C$. stercorarium and probably binds to the cell surface [74]. CBM61 binds to $\beta$ - $(1,4)$-galactan [75], indicating that the full-length protein has a similar activity to the shortened variant of Gal53A, which was tested here. In accordance with the common activity for $\mathrm{GH}$ family 35 , Bga35A showed $\beta$-galactosidase activity towards galactans [69].

\section{Hydrolysis of aryl-glycosides}

For 15 glycosidases only $p$ NP-glycoside-cleaving activities were determined. Beside the previously characterised enzymes Bxl39A, Bgl3Z, Xyl43A, Xyl43B, and Ram78A, the activity screening revealed ten new enzymes: $\beta$-D-galactosidases Bga2C, Bga2D, and Bga2E; $\beta$-D-xylosidases Bxl43C and Bxl31D; $\beta$-D-glucosidase BglA; $\alpha$-L-arabinofuranosidase ArfD; $\alpha$-L-rhamnosidase RamB; $\beta$-D-glucuronidase Uid2A; and $N$-acetyl- $\beta$-Dglucosaminidase Nag3A [16, 17, 23, 28]. Determined activities of Bga2C-E, Uid2A, Bxl43C, and Nag3A are in accordance with the predicted activity of their respective 
GH families $[68,69,76]$. Interestingly, enzymes of the GH family 31 are often $\alpha$-glycosidases while Bxl31D hydrolysed exclusively $p$ NP- $\beta$-D-xylopyranoside, thereby adding a new activity to the GH family $31[38,69]$. It can be assumed that the aryl-glycosidic activity corresponds to an alkyl-glycosidic activity on polymeric and oligomeric substrates. The enzymes BglA, ArfD, and RamB contain $\mathrm{GH}$ modules that have not yet been assigned to a $\mathrm{GH}$ family. They could be the first characterised enzymes that define new GH families. To clarify this, further experiments are needed.

\section{Conclusions}

Clostridium stercorarium serves as a model organism for the degradation of lignocellulosic biomass, especially for the hydrolysis of hemicellulose. However, only enzymes for the degradation of cellulose and xylan have been well characterised so far [12, 35]. In this study we systematically investigated the majority of glycoside hydrolases from C. stercorarium DSM 8532 and we present 20 new enzymes for the bioconversion of hemicellulose. We characterised the first $C$. stercorarium enzymes involved in the degradation of xyloglucan, mannan as well as galacto- and glucomannan, arabinan, and galactan. The determined activities of native extracellular and recombinantly produced enzymes lead to a better understanding of the hemicellulose-degrading capacity of the bacterium and the involved enzymes. Additionally, we discovered new activities not reported before for the $\mathrm{GH}$ families 31 and 105 and present three enzymes possibly belonging to new $\mathrm{GH}$ families. While the optimal temperature for the majority of the characterised enzymes $\left(57-76{ }^{\circ} \mathrm{C}\right)$ matches the optimum growth temperature of C. stercorarium $\left(60-70{ }^{\circ} \mathrm{C}\right)$, the enzymes prefer a slightly more acidic $\mathrm{pH}$ than the bacterium, $\mathrm{pH}$ 5.0-6.5 instead of $\mathrm{pH} 7.3$ [10].

Enzyme combinations selected from the newly characterised glycoside hydrolases, especially of enzymes with endo- and exo-activity, could lead to a complete degradation of mixed linkage glucan, arabinan or galactan to monosaccharides, as previously described for arabinoxylan [17]. However, further studies will be needed to reconstitute the $C$. stercorarium specific enzyme systems for the complete degradation of defined polysaccharides and hemicellulose. The degradation of xyloglucan or mannan requires at least one xyloglucanase and one $\beta$-mannosidase, respectively, activities that have not yet been identified in C. stercorarium [4]. In combination with activity assays, proteomic analyses of the C. stercorarium secretomes secreted in the presence of various polysaccharides could be applied to identify the enzymes the bacterium employs to their degradation. The hydrolysis of complex polysaccharides requires further accessory enzymes like carbohydrate esterases (CE) and polysaccharide lyases $(\mathrm{PL})$, which were not subject of this study [8].

Detailed substrate and product specificities as determined for xylanases, $\alpha$-arabinofuranosidases and $\beta$-xylosidases increase the understanding of the reaction mechanism and provide a promising platform for biotechnological applications. Such applications often require highly specific activities. Especially $\alpha-\mathrm{L}-$ arabinofuranosidases with the ability to hydrolyse single and double substitutions, like Arf51B and Axh43A, are of great interest because these substitutions inhibit or even prevent arabinoxylan and pectin from complete degradation to their monomers $[2,67]$.

Bacteria active in hemicellulose degradation such as $C$. stercorarium are a rich source of specific enzyme activities needed for industrial applications. By cloning hitherto unknown gene families, as done in this study, even new protein families can be detected.

\section{Additional files}

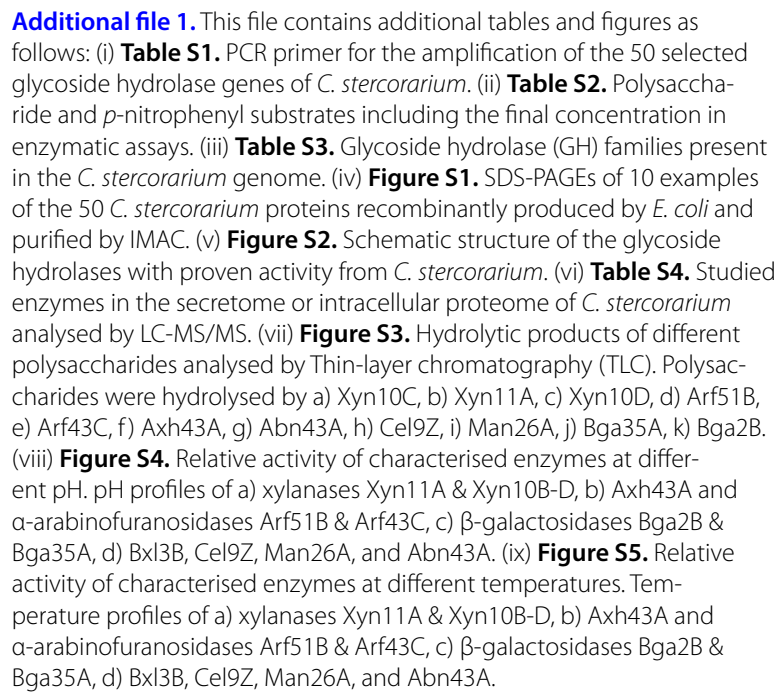

Additional file 2. This file contains the complete processed data set of the LC-MS/MS proteome analysis: LC-MS/MS data of the secretome (SU) and the intracellular proteome (PE) of C. stercorarium.

\section{Abbreviations}

Abn: arabinanase; Arf: a-arabinofuranosidase; Axh: arabinoxylan arabinofuranohydrolase; Bga: $\beta$-galactosidase; Bgl: $\beta$-glucosidase; Bxl: $\beta$-xylosidase; CAZy: Carbohydrate-Active enZYme database; CBM: carbohydrate binding module; Cel: cellulase; DNSA: 3,5-dinitrosalicylic acid; Gal: galactanase; GH: glycoside hydrolase; HPAEC-PAD: high-performance anion-exchange chromatography with pulsed amperometric detection; iBAQ: intensity based absolute quantification; ISTD: internal standard; Man: mannanase; MOPS: 3-(N-morpholino)propanesulfonic acid; Nag: $N$-acetyl- $\beta$-D-glucosaminidase; Ram: rhamnosidase; TLC: thin-layer chromatography; Uid: $\beta$-D-glucuronidase; Xyl: xylosidase; Xyn: xylanase. 


\section{Authors' contributions}

$\mathrm{JB}$ isolated the extracellular proteins, produced the recombinant proteins, carried out the activity assays, the analyses of the hydrolytic products and product specificity by TLC and HPAEC-PAD, and drafted the manuscript. MM carried out the oligosaccharide hydrolyses and the analysis of the substrate specificity by HPAEC-PAD, assisted by the HPAEC-PAD analysis and drafted parts of the manuscript. MB replicated activity assays with polysaccharides and recombinant enzymes. DS carried out activity assays with recombinant enzymes on pNP-glycosides. DH performed LC MS/MS sample preparation, raw data analysis and drafted a section of the methods. DH and MM designed nano LC MS/ MS label free identification and quantification strategies for C. stercorariums cellular proteome and secretome. WZ: isolated extracellular and intracellular proteins for proteomic analysis by LC-MS/MS, analysed proteomics data and revised the manuscript. WHS participated in the design of the joint project, supervised the work package and revised the manuscript. WL contributed to the design of the joint project, supervised the work package and revised the manuscript. All authors read and approved the final manuscript.

\section{Author details}

${ }^{1}$ Department of Microbiology, TUM School of Life Sciences Weihenstephan, Technical University of Munich, Emil-Ramann-Str. 4, 85354 Freising, Germany. 2 Present Address: School of Medicine, Stanford University, Stanford, CA 94305, USA. ${ }^{3}$ Max Planck Institute of Biochemistry, Am Klopferspitz 18, 82152 Martinsried, Germany. ${ }^{4}$ Institute of Molecular Genetics, Russian Academy of Science, Kurchatov Sq. 2, Moscow 123182, Russia.

\section{Acknowledgements}

Financial support from the European Union's Seventh Framework Programme and from the German Federal Ministry of Education and Research is gratefully acknowledged. The authors thank Jonathan Herlet for assistance with the HPAEC-PAD analysis, Ursula Rambold and Tobias Wörl for assistance in conducting the $p N P$ assays and Simon Heinze for helpful comments on the manuscript.

\section{Competing interests}

The authors declare that they have no competing interests.

\section{Availability of data and materials}

The genome sequence (NC_020134.1) of C. stercorarium DSM 8532 is available at the National Center for Biotechnology Information under accession number NC_020134.1. A list of all carbohydrate-active enzymes of C. stercorarium is available in the CAZy database. All data generated or analysed during this study are included in this published article and its additional files.

\section{Consent for publication}

Not applicable.

\section{Ethics approval and consent to participate}

Not applicable.

\section{Funding}

This work received funding from the European Union's Seventh Framework Programme (FP7-KBBE-2013-7) as part of the collaborative project Valor Plus under Grant Agreement No. 613802 and from the German Federal Ministry of Education and Research (BMBF, 031B0267B within the ERA-IB consortium YEASTPEC).

\section{Publisher's Note}

Springer Nature remains neutral with regard to jurisdictional claims in published maps and institutional affiliations.

Received: 11 June 2018 Accepted: 14 Auqust 2018

Published online: 23 August 2018

\section{References}

1. Scheller HV, Ulvskov P. Hemicelluloses. Annu Rev Plant Biol. 2010;61:263-89.
2. Saha BC. Hemicellulose bioconversion. J Ind Microbiol Biotechnol. 2003;30:279-91.

3. Pauly M, Keegstra K. Cell-wall carbohydrates and their modification as a resource for biofuels. Plant J. 2008;54:559-68.

4. Alvarez C, Reyes-Sosa FM, Diez B. Enzymatic hydrolysis of biomass from wood. Microb Biotechnol. 2016;9:149-56.

5. Ebringerová A, Hromádková Z, Heinze T. Hemicellulose. In: Heinze T, editor. Polysaccharides I: structure, characterization and use. Berlin: Springer; 2005. p. 1-67.

6. Westbye P, Svanberg C, Gatenholm P. The effect of molecular composition of xylan extracted from birch on its assembly onto bleached softwood kraft pulp. Holzforschung. 2006;60:143-8.

7. Henrissat B, Davies G. Structural and sequence-based classification of glycoside hydrolases. Curr Opin Struct Biol. 1997;7:637-44.

8. Lombard V, Golaconda Ramulu H, Drula E, Coutinho PM, Henrissat B. The carbohydrate-active enzymes database (CAZy) in 2013. Nucleic Acids Res. 2014;42:D490-5.

9. Himmel ME, Xu Q, Luo Y, Ding S-Y, Lamed R, Bayer EA. Microbial enzyme systems for biomass conversion: emerging paradigms. Biofuels. 2010:1:323-41.

10. Madden $\mathrm{RH}$. Isolation and characterization of Clostridium stercorarium sp. nov., cellulolytic thermophile. Int J Syst Bacteriol. 1983;33:837-40.

11. Poehlein A, Zverlov W, Daniel R, Schwarz WH, Liebl W. Complete genome sequence of Clostridium stercorarium subsp. stercorarium Strain DSM 8532, a thermophilic degrader of plant cell wall fibers. Genome Announc. 2013;1:e0007313.

12. Zverlov WV, Schwarz WH. Bacterial cellulose hydrolysis in anaerobic environmental subsystems-Clostridium thermocellum and Clostridium stercorarium, thermophilic plant-fiber degraders. Ann N Y Acad Sci. 2008;1125:298-307.

13. Schwarz WH, Bronnenmeier K, Landmann B, Wanner G, Staudenbauer WL, Kurose N, et al. Molecular characterization of four strains of the cellulolytic thermophile Clostridium stercorarium. Biosci Biotechnol Biochem. 1995;59:1661-5.

14. Zverlov W, HiegI W, Kock DE, Kellermann J, Kollmeier T, Schwarz WH. Hydrolytic bacteria in mesophilic and thermophilic degradation of plant biomass. Eng Life Sci. 2010;10:528-36.

15. Yutin N, Galperin MY. A genomic update on clostridial phylogeny: gramnegative spore formers and other misplaced clostridia. Environ Microbiol. 2013;15:2631-41.

16. Zverlov W, Hertel C, Bronnenmeier K, Hroch A, Kellermann J, Schwarz $\mathrm{WH}$. The thermostable alpha-L-rhamnosidase RamA of Clostridium stercorarium: biochemical characterization and primary structure of a bacterial alpha-L-rhamnoside hydrolase, a new type of inverting glycoside hydrolase. Mol Microbiol. 2000;35:173-9.

17. Adelsberger H, Hertel C, Glawischnig E, Zverlov W, Schwarz WH. Enzyme system of Clostridium stercorarium for hydrolysis of arabinoxylan: reconstitution of the in vivo system from recombinant enzymes. Microbiology. 2004;150:2257-66.

18. Riedel K, Ritter J, Bronnenmeier K. Synergistic interaction of the Clostridium stercorarium cellulases avicelase I (CelZ) and avicelase II (CelY) in the degradation of microcrystalline cellulose. FEMS Microbiol Lett. 1997:147:239-43.

19. Bronnenmeier K, Staudenbauer WL. Cellulose hydrolysis by a highly thermostable endo-1,4-beta-glucanase (avicelase I) from Clostridium stercorarium. Enzyme Microb Technol. 1990;12:431-6.

20. Jauris S, Rucknagel KP, Schwarz WH, Kratzsch P, Bronnenmeier K, Staudenbauer WL. Sequence analysis of the Clostridium stercorarium celZ gene encoding a thermoactive cellulase (avicelase I): identification of catalytic and cellulose-binding domains. Mol Gen Genet. 1990;223:258-67.

21. Bronnenmeier K, Rucknagel KP, Staudenbauer WL. Purification and properties of a novel type of exo-1,4-beta-glucanase (avicelase II) from the cellulolytic thermophile Clostridium stercorarium. Eur J Biochem. 1991:200:379-85.

22. Bronnenmeier K, Kundt K, Riedel K, Schwarz WH, Staudenbauer WL. Structure of the Clostridium stercorarium gene celY encoding the exo-1,4-betaglucanase avicelase II. Microbiology. 1997;143(Pt 3):891-8.

23. Sakka K, Kojima Y, Kondo T, Karita S, Ohmiya K, Shimada K. Nucleotide sequence of the Clostridium stercorarium xynA gene encoding xylanase A identification of catalytic and cellulose binding domains. Biosci Biotechnol Biochem. 1993:57:273-7. 
24. Fukumura M, Sakka K, Shimada K, Ohmiya K. Nucleotide sequence of the Clostridium stercorarium xynB gene encoding an extremely thermostable xylanase, and characterization of the translated product. Biosci Biotechnol Biochem. 1995;59:40-6.

25. Ali MK, Fukumura M, Sakano K, Karita S, Kimura T, Sakka K, et al. Cloning, sequencing, and expression of the gene encoding the Clostridium stercorarium xylanase C in Escherichia coli. Biosci Biotechnol Biochem. 1999;63:1596-604.

26. Schwarz WH, Adelsberger H, Jauris S, Hertel C, Funk B, Staudenbauer WL. Xylan degradation by the thermophile Clostridium stercorarium: cloning and expression of xylanase, beta-D-xylosidase, and alpha-L-arabinofuranosidase genes in Escherichia coli. Biochem Biophys Res Commun. 1990;170:368-74.

27. Sakka K, Yoshikawa K, Kojima Y, Karita S, Ohmiya K, Shimada K. Nucleotide sequence of the Clostridium stercorarium xylA gene encoding a bifunctional protein with beta-D-xylosidase and alpha-L-arabinofuranosidase activities, and properties of the translated product. Biosci Biotechnol Biochem. 1993:57:268-72.

28. Suryani, Kimura T, Sakka K, Ohmiya K. Sequencing and expression of the gene encoding the Clostridium stercorarium beta-xylosidase Xyl43B in Escherichia coli. Biosci Biotechnol Biochem. 2004;68:609-14.

29. Suryani, Kimura T, Sakka K, Ohmiya K. Cloning, sequencing, and expression of the gene encoding the Clostridium stercorarium alphagalactosidase Aga36A in Escherichia coli. Biosci Biotechnol Biochem. 2003;67:2160-6

30. Bronnenmeier K, Meissner H, Stocker S, Staudenbauer WL. alpha-D-glucuronidases from the xylanolytic thermophiles Clostridium stercorarium and Thermoanaerobacterium saccharolyticum. Microbiology. 1995;141(Pt 9):2033-40.

31. Kaur A, Singh S, Singh RS, SchwarzWH, Puri M. Hydrolysis of citrus peel naringin by recombinant alpha-L-rhamnosidase from Clostridium stercorarium. J Chem Technol Biotechnol. 2010;85:1419-22.

32. Donaghy JA, Bronnenmeier K, Soto-Kelly PF, McKay AM. Purification and characterization of an extracellular feruloyl esterase from the thermophilic anaerobe Clostridium stercorarium. J Appl Microbiol. 2000;88:458-66

33. Si Si H, Kurokawa J, Suryani, Kimura T, Ohmiya K, Sakka K. A novel thermophilic pectate lyase containing two catalytic modules of Clostridium stercorarium. Biosci Biotechnol Biochem. 2005;69:2138-45.

34. Reichenbecher M, Lottspeich F, Bronnenmeier K. Purification and properties of a cellobiose phosphorylase (CepA) and a cellodextrin phosphorylase (CepB) from the cellulolytic thermophile Clostridium stercorarium. Eur J Biochem. 1997;247:262-7.

35. Koeck DE, Pechtl A, Zverlov W, Schwarz WH. Genomics of cellulolytic bacteria. Curr Opin Biotechnol. 2014;29:171-83.

36. Johnson EA, Madia A, Demain AL. Chemically defined minimal medium for growth of the anaerobic cellulolytic thermophile Clostridium thermocellum. Appl Environ Microbiol. 1981;41:1060-2.

37. Koeck DE, Ludwig W, Wanner G, Zverlov W, Liebl W, Schwarz WH. Herbinix hemicellulosilytica gen. nov., sp. nov., a thermophilic cellulose-degrading bacterium isolated from a thermophilic biogas reactor. Int J Syst Evol Microbiol. 2015;65:2365-71.

38. Architecture et Fonction des Macromolécules Biologiques: CarbohydrateActive Enzymes database. 2014. http://www.cazy.org/. Accessed 24 July 2014.

39. National Center for Biotechnology Information. National Library of Medicine, Bethesda. 2014. https://www.ncbi.nlm.nih.gov/. Accessed 24 July 2014.

40. Gibson DG. Synthesis of DNA fragments in yeast by one-step assembly of overlapping oligonucleotides. Nucleic Acids Res. 2009;37:6984-90.

41. Crowe J, Masone BS, Ribbe J. One-step purification of recombinant proteins with the $6 \times$ His tag and Ni-NTA resin. In: Harwood AJ, editor. Basic DNA and RNA protocols methods in molecular biology, vol. 58. Totowa: Humana Press; 1996. p. 491-510.

42. DTU Bioinformatics: SignalP 4.1 Server. 2014. http://www.cbs.dtu.dk/servi ces/SignalP/. Accessed 25 July 2014

43. Petersen TN, Brunak S, von Heijne G, Nielsen H. SignalP 4.0: discriminating signal peptides from transmembrane regions. Nat Methods. 2011;8:785-6.

44. Studier FW. Protein production by auto-induction in high density shaking cultures. Protein Expr Purif. 2005:41:207-34.
45. Mechelke M, Koeck DE, Broeker J, Roessler B, Krabichler F, Schwarz $\mathrm{WH}$, et al. Characterization of the arabinoxylan-degrading machinery of the thermophilic bacterium Herbinix hemicellulosilytica-six new xylanases, three arabinofuranosidases and one xylosidase. J Biotechnol. 2017:257:122-30

46. Laemmli UK. Cleavage of structural proteins during the assembly of the head of bacteriophage T4. Nature. 1970;227:680-5.

47. Swiss Institute of Bioinformatics. ExPASy: SIB bioinformatics resource portal. 2014. https://www.expasy.org/. Accessed 04 Nov 2014.

48. Gasteiger E, Hoogland C, Gattiker A, Duvaud S, Wilkins MR, Appel RD, et al. Protein identification and analysis tools on the ExPASy Server. In: Walker JM, editor. The proteomics protocols handbook. New York: Totowa; 2005. p. 571-607.

49. Hornburg D, Drepper C, Butter F, Meissner F, Sendtner M, Mann M. Deep proteomic evaluation of primary and cell line motoneuron disease models delineates major differences in neuronal characteristics. Mol Cell Proteomics. 2014;13:3410-20.

50. Schwanhausser B, Busse D, Li N, Dittmar G, Schuchhardt J, Wolf J, et al. Global quantification of mammalian gene expression control. Nature. 2011:473:337-42.

51. Cox J, Mann M. MaxQuant enables high peptide identification rates, individualized ppb-range mass accuracies and proteome-wide protein quantification. Nat Biotechnol. 2008;26:1367-72.

52. Wood TM, Bhat KM. Methods for measuring cellulase activities. Methods Enzymol. 1988;160:87-112.

53. Zverlov W, Velikodvorskaya GA, Schwarz WH. Two new cellulosome components encoded downstream of cell in the genome of Clostridium thermocellum: the non-processive endoglucanase CelN and the possibly structural protein CseP. Microbiology. 2003;149:515-24.

54. Schwarz WH, Brunecky R, Broeker J, Liebl W, Zverlov W. Handling gene and protein names in the age of bioinformatics: the special challenge of secreted multimodular bacterial enzymes such as the cbhA/cbh9A gene of Clostridium thermocellum. World J Microbiol Biotechnol. 2018:34:42.

55. Boraston AB, Bolam DN, Gilbert HJ, Davies GJ. Carbohydrate-binding modules: fine-tuning polysaccharide recognition. Biochem J. 2004;382:769-81.

56. Schwarz WH, Bronnenmeier K, Krause B, Lottspeich F, Staudenbauer WL. Debranching of arabinoxylan: properties of the thermoactive recombinant alpha-L-arabinofuranosidase from Clostridium stercorarium (ArfB). Appl Microbiol Biotechnol. 1995;43:856-60.

57. Finn RD, Coggill P, Eberhardt RY, Eddy SR, Mistry J, Mitchell AL, et al. The Pfam protein families database: towards a more sustainable future. Nucleic Acids Res. 2016;44:D279-85.

58. European Bioinformatics Institute: Pfam database. 2017. https://pfam. xfam.org/. Accessed 24 July 2017.

59. Maus I, Koeck DE, Cibis KG, Hahnke S, Kim YS, Langer T, et al. Unraveling the microbiome of a thermophilic biogas plant by metagenome and metatranscriptome analysis complemented by characterization of bacterial and archaeal isolates. Biotechnol Biofuels. 2016:9:171.

60. Sun JL, Sakka K, Karita S, Kimura T, Ohmiya K. Adsorption of Clostridium stercorarium xylanase A to insoluble xylan and the importance of the CBDs to xylan hydrolysis. J Ferment Bioeng. 1998;85:63-8.

61. Zhao G, Ali E, Araki R, Sakka M, Kimura T, Sakka K. Function of the family-9 and family-22 carbohydrate-binding modules in a modular beta-1,3-1,4glucanase/xylanase derived from Clostridium stercorarium Xyn10B. Biosci Biotechnol Biochem. 2005;69:1562-7.

62. Riedel K, Ritter J, Bauer S, Bronnenmeier K. The modular cellulase CelZ of the thermophilic bacterium Clostridium stercorarium contains a thermostabilizing domain. FEMS Microbiol Lett. 1998;164:261-7.

63. Stam MR, Danchin EG, Rancurel C, Coutinho PM, Henrissat B. Dividing the large glycoside hydrolase family 13 into subfamilies: towards improved functional annotations of alpha-amylase-related proteins. Protein Eng Des Sel. 2006;19:555-62.

64. Biely P, Singh S, Puchart V. Towards enzymatic breakdown of complex plant xylan structures: state of the art. Biotechnol Adv. 2016;34:1260-74.

65. Itoh T, Ochiai A, Mikami B, Hashimoto W, Murata K. A novel glycoside hydrolase family 105: the structure of family 105 unsaturated rhamnogalacturonyl hydrolase complexed with a disaccharide in comparison with family 88 enzyme complexed with the disaccharide. J Mol Biol. 2006;360:573-85. 
66. Berenger JF, Frixon C, Bigliardi J, Creuzet N. Production, purification, and properties of thermostable xylanase from Clostridium stercorarium. Can Microbiol. 1985;31:635-43.

67. Numan MT, Bhosle NB. Alpha-L-arabinofuranosidases: the potential applications in biotechnology. J Ind Microbiol Biotechnol. 2006;33:247-60.

68. Mewis K, Lenfant N, Lombard V, Henrissat B. Dividing the large glycoside hydrolase family 43 into subfamilies: a motivation for detailed enzyme characterization. Appl Environ Microbiol. 2016;82:1686-92.

69. Henrissat B. A classification of glycosyl hydrolases based on amino acid sequence similarities. Biochem J. 1991;280(Pt 2):309-16.

70. Bolam DN, Xie H, Pell G, Hogg D, Galbraith G, Henrissat B, et al. X4 modules represent a new family of carbohydrate-binding modules that display novel properties. J Biol Chem. 2004;279:22953-63.

71. Verhertbruggen Y, Marcus SE, Haeger A, Verhoef R, Schols HA, McCleary $\mathrm{BV}$, et al. Developmental complexity of arabinan polysaccharides and their processing in plant cell walls. Plant J. 2009:59:413-25.

72. Ridley BL, O'Neill MA, Mohnen D. Pectins: structure, biosynthesis, and oligogalacturonide-related signaling. Phytochemistry. 2001;57:929-67.
73. Verhoef R, Lu Y, Knox JP, Voragen AG, Schols HA. Fingerprinting complex pectins by chromatographic separation combined with ELISA detection. Carbohydr Res. 2009;344:1808-17.

74. Mesnage S, Fontaine T, Mignot T, Delepierre M, Mock M, Fouet A. Bacterial SLH domain proteins are non-covalently anchored to the cell surface via a conserved mechanism involving wall polysaccharide pyruvylation. EMBO J. 2000;19:4473-84.

75. Cid M, Pedersen HL, Kaneko S, Coutinho PM, Henrissat B, Willats WG, et al. Recognition of the helical structure of beta-1,4-galactan by a new family of carbohydrate-binding modules. J Biol Chem. 2010;285:35999-6009.

76. Macdonald SS, Blaukopf M, Withers SG. N-acetylglucosaminidases from CAZy family $\mathrm{GH} 3$ are really glycoside phosphorylases, thereby explaining their use of histidine as an acid/base catalyst in place of glutamic acid. J Biol Chem. 2015:290:4887-95.
Ready to submit your research? Choose BMC and benefit from

- fast, convenient online submission

- thorough peer review by experienced researchers in your field

- rapid publication on acceptance

- support for research data, including large and complex data types

- gold Open Access which fosters wider collaboration and increased citations

- maximum visibility for your research: over $100 \mathrm{M}$ website views per year

At BMC, research is always in progress.

Learn more biomedcentral.com/submissions 